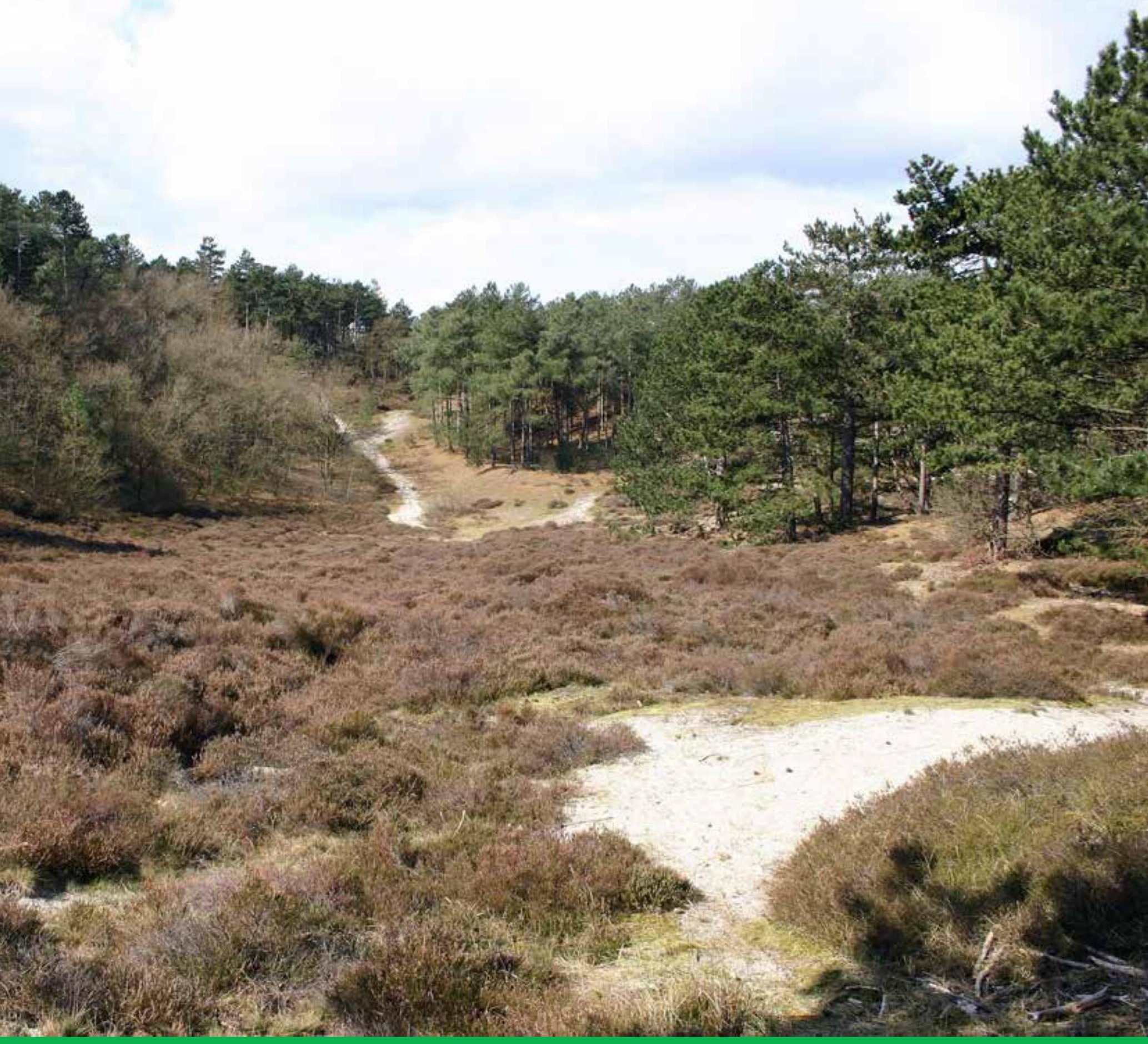

\title{
Evaluatie fiscale vrijstellingen bos en natuur
}

Huib Silvis en Harold van der Meulen 



\section{Evaluatie fiscale vrijstellingen bos en natuur}

Huib Silvis en Harold van der Meulen

Dit onderzoek is uitgevoerd door Wageningen Economic Research in opdracht van en gefinancierd door het ministerie van Economische Zaken.

Wageningen Economic Research

Wageningen, oktober 2016

RAPPORT

2016-090

ISBN 978-94-6257-973-6 
Silvis, H.J. en H.A.B. van der Meulen, 2016. Evaluatie fiscale vrijstellingen bos en natuur. Wageningen, Wageningen Economic Research, Rapport 2016-090. 44 blz.; 6 fig.; 10 tab.; 16 ref.

Deze evaluatie is gewijd aan zes fiscale vrijstellingen voor bos en natuur. Deze vrijstellingen in respectievelijk inkomstenbelasting, vennootschapsbelasting en overdrachtsbelasting hebben een ondersteunende functie in het Nederlandse bos- en natuurbeleid. Het zijn kleine faciliteiten in budgettair opzicht. Gegevens over gebruik en effecten van de vrijstellingen zijn slechts beperkt vastgelegd. Door interviews is inzicht verkregen in hoe verschillende groepen betrokkenen de werking en effecten van de vrijstellingen beoordelen. Geconcludeerd wordt dat de vrijstellingen bijdragen aan het bereiken van doelen van het overheidsbeleid en geen hoge administratieve lasten en uitvoeringskosten met zich meebrengen.

This evaluation is devoted to six tax exemptions for forested areas and other natural areas. These exemptions in income tax, corporation tax, and transfer tax respectively have a supporting role in Dutch forest and nature conservation policy. These are small-scale facilities from a budgetary perspective. Data on the use and effects of the exemptions have only been recorded to a limited extent. Through interviews, insight has been gained into how different groups of stakeholders assess the workings and effects of the exemptions. The conclusion can be drawn that the exemptions contribute to the achievement of the goals of the government's policy, and are not accompanied by excessive administrative burdens or high implementation costs.

Trefwoorden: bosbouwvrijstelling, vrijstelling vergoedingen bos en natuur, grondslag sparen en beleggen, overdrachtsbelasting, WILG-vrijstelling, BBL-vrijstelling

Dit rapport is gratis te downloaden op http://dx.doi.org/10.18174/393129 of op www.wur.nl/economic-research (onder Wageningen Economic Research publicaties).

(C) 2016 Wageningen Economic Research

Postbus 29703, 2502 LS Den Haag, T 07033583 30, E communications.ssg@wur.nl, www. wur.nl/economic-research. Wageningen Economic Research is onderdeel van Wageningen University \& Research.

\section{(cc) BY-NC}

Wageningen Economic Research hanteert voor haar rapporten een Creative Commons Naamsvermelding 3.0 Nederland licentie.

(C) Wageningen Economic Research, onderdeel van Stichting Wageningen Research, 2016 De gebruiker mag het werk kopiëren, verspreiden en doorgeven en afgeleide werken maken. Materiaal van derden waarvan in het werk gebruik is gemaakt en waarop intellectuele eigendomsrechten berusten, mogen niet zonder voorafgaande toestemming van derden gebruikt worden. De gebruiker dient bij het werk de door de maker of de licentiegever aangegeven naam te vermelden, maar niet zodanig dat de indruk gewekt wordt dat zij daarmee instemmen met het werk van de gebruiker of het gebruik van het werk. De gebruiker mag het werk niet voor commerciële doeleinden gebruiken.

Wageningen Economic Research aanvaardt geen aansprakelijkheid voor eventuele schade voortvloeiend uit het gebruik van de resultaten van dit onderzoek of de toepassing van de adviezen.

Wageningen Economic Research is ISO 9001:2008 gecertificeerd. 


\section{Inhoud}

Woord vooraf $\quad 5$

$\begin{array}{ll}\text { Samenvatting } & 6\end{array}$

$\begin{array}{lll}\text { S.1 Belangrijkste uitkomsten } & 6\end{array}$

S.2 Vraagstelling en methode $\quad 8$

$\begin{array}{ll}\text { Summary } & 9\end{array}$

S.1 Key findings $\quad 9$

S.2 Research question and method $\quad 11$

1

Inleiding $\quad 12$

$1.1 \quad$ Aanleiding $\quad 12$

1.2 Doel en afbakening $\quad 12$

1.3 Onderzoeksvragen 13

$\begin{array}{lll}1.4 & \text { Methode } & 13\end{array}$

$2 \quad$ Bosbouwvrijstelling $r$

$\begin{array}{lll}2.1 & \text { Beleidstheorie } & 15\end{array}$

2.2 Doeltreffendheid 16

$\begin{array}{lll}2.3 & \text { Doelmatigheid } & 17\end{array}$

$3 \quad$ Vrijstelling vergoeding bos- en natuurbeheer $r$

$\begin{array}{lll}3.1 & \text { Beleidstheorie } & 19\end{array}$

$\begin{array}{lll}3.2 & \text { Doeltreffendheid } & 20\end{array}$

$\begin{array}{lll}3.3 & \text { Doelmatigheid } & 21\end{array}$

$4 \quad$ Vrijstelling bos- en natuurterreinen bij voordeel uit sparen en beleggen 22

$\begin{array}{lll}4.1 & \text { Beleidstheorie } & 22\end{array}$

$\begin{array}{lll}4.2 & \text { Doeltreffendheid } & 23\end{array}$

$\begin{array}{lll}4.3 & \text { Doelmatigheid } & 23\end{array}$

$5 \quad$ Vrijstelling overdrachtsbelasting natuurgrond $\quad 25$

$\begin{array}{lll}5.1 & \text { Beleidstheorie } & 25\end{array}$

$\begin{array}{lll}5.2 & \text { Doeltreffendheid } & 26\end{array}$

$\begin{array}{lll}5.3 & \text { Doelmatigheid } & 27\end{array}$

$6 \quad$ Vrijstelling overdrachtsbelasting Wet Inrichting Landelijk Gebied (WILG) 29

$\begin{array}{lll}6.1 & \text { Beleidstheorie } & 29 \\ 6.2 & \text { Doeltreffendheid } & 30 \\ 6.3 & \text { Doelmatigheid } & 30\end{array}$

$7 \quad$ Vrijstelling verkrijging door Bureau Beheer Landbouwgronden (BBL) 33

$\begin{array}{lll}7.1 & \text { Beleidstheorie } & 33\end{array}$

$\begin{array}{lll}7.2 & \text { Doeltreffendheid } & 34\end{array}$

$\begin{array}{lll}7.3 & \text { Doelmatigheid } & 34\end{array}$

$\begin{array}{ll}\text { Literatuur en websites } & 36\end{array}$

$\begin{array}{lll}\text { Bijlage } 1 \text { Geraadpleegde personen } & 37\end{array}$

Bijlage 2 Bos en natuur in Nederland: enkele kerncijfers 38 



\section{Woord vooraf}

Fiscale vrijstellingen kunnen een doeltreffende en doelmatige bijdrage leveren aan het bereiken van doelen van het overheidsbeleid. Deze evaluatie is gewijd aan een zestal vrijstellingen voor bos en natuur (buiten de Natuurschoonwet 1928). De vrijstellingen hebben betrekking op de inkomstenbelasting, de vennootschapsbelasting en de overdrachtsbelasting. Over de benutting van de vrijstellingen, het budgettaire belang en de effecten ervan zijn weinig harde gegevens beschikbaar. Voor veel vrijstellingen worden geen separate data bijgehouden. Het is niet goed mogelijk om de effecten van de vrijstellingen te isoleren van die van het bredere instrumentarium van het natuurbeleid. De evaluatie heeft dan ook een kwalitatief karakter. Op basis van gesprekken met experts wordt geconcludeerd dat de vrijstellingen bijdragen aan het bereiken van doelen van het overheidsbeleid en geen hoge administratieve lasten en uitvoeringskosten met zich meebrengen. Dat neemt niet weg dat aanpassingen de moeite van het overwegen waard zijn.

De evaluatie is verricht in opdracht van het ministerie van Economische Zaken. Namens de opdrachtgever is het onderzoek begeleid door een commissie onder leiding van Rob Smit. Daarnaast maakten Ilona van de Velde (ministerie van EZ), Frank Harms (ministerie van EZ) en Jordy Huis (ministerie van Financiën) deel uit van de commissie.

Het onderzoek is uitgevoerd door Huib Silvis (projectleider) en Harold van der Meulen (beiden Wageningen Economic Research, voorheen LEI Wageningen UR). Daarnaast was Aris Gaaff (oud Wageningen Economic Research-medewerker, evaluatie-expert) als adviseur betrokken bij de evaluatie. In de rol van themaleider BO (Natuurinclusieve economie en natuurcombinaties) heeft ook Stijn Reinhard aan dit onderzoek bijgedragen.

De bevindingen van het onderzoek zijn in belangrijke mate gebaseerd op interviews met mensen die direct en indirect bij de vrijstellingen betrokken zijn. De geraadpleegde personen zijn vermeld in bijlage 1 . Behalve aan deze mensen is ook veel dank verschuldigd aan de begeleidingscommissie voor de constructieve samenwerking.

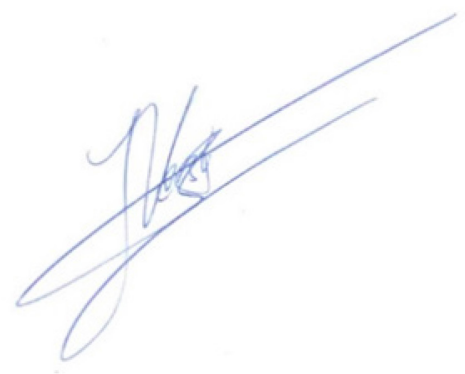

Prof. dr ir. Jack (J.G.A.J.) van der Vorst Algemeen Directeur Social Sciences Group Wageningen University \& Research 


\section{Samenvatting}

\section{S.1 Belangrijkste uitkomsten}

\section{Algemeen}

In het Nederlandse bos- en natuurbeleid hebben fiscale vrijstellingen een ondersteunende functie. De bosbouwvrijstelling draagt bij aan het bosbeheer door ondernemingen. De vrijstelling voor vergoedingen in bos- en natuurbeheer zorgt ervoor dat de betreffende subsidies lager kunnen blijven om hetzelfde effect te bereiken. De vrijstelling van natuur bij voordeel uit sparen en beleggen draagt bij aan de aantrekkelijkheid van het particuliere bezit van bos en natuur. Naast deze drie vrijstellingen voor de inkomstenbelasting, zijn er vrijstellingen van de overdrachtsbelasting. De vrijstelling overdrachtsbelasting natuurgronden bevordert de aantrekkelijkheid van natuur als investeringsobject. De vrijstelling overdrachtsbelasting Wet Inrichting Landelijk Gebied (WILG) draagt bij aan de structuurverbetering van het landelijk gebied. Van oudsher geldt dit ook voor de vrijstelling van Bureau Beheer Landbouwgronden (BBL). De zes genoemde vrijstellingen zijn goed bekend bij en aantrekkelijk voor de onderscheiden doelgroepen, vooral ten aanzien van de administratieve lasten. Ook de uitvoeringskosten voor de overheid zijn gering. Deze evaluatie gaat nader in op de doeltreffendheid en doelmatigheid van de vrijstellingen.

\section{Bosbouwvrijstelling}

De bosbouwvrijstelling is een objectieve vrijstelling die bepaalt dat de winst van het bosbedrijf niet belast is. De vrijstelling geldt voor iedere ondernemer/onderneming die bos exploiteert. Daar staat tegenover dat als de lasten van het bosbedrijf de baten overtreffen, het negatieve saldo niet aftrekbaar is van elders genoten inkomsten. Nagenoeg alle bosbedrijven maken er gebruik van, evenals een aantal andere bedrijven. De optieregeling, die is ingesteld om wel voor het belaste regime te kunnen kiezen, wordt nauwelijks gebruikt. Het is aannemelijk dat de vrijstelling bijdraagt aan het bosbeheer door ondernemingen, maar het is niet te bepalen in welke mate ze bijdraagt aan de instandhouding van het bosareaal. Het budgettair belang wordt in de Miljoenennota's 2012-2016 geschat op 1 miljoen euro per jaar. Tegen de achtergrond van de gestegen bedrijfsresultaten van de particuliere bosbouw in de afgelopen jaren is dat vermoedelijk een onderschatting van het werkelijke belang. Voor zover de bosbouwvrijstelling van toepassing is, is het bepalen van de winst van het bosbouwbedrijf niet nodig. Wanneer de vrijstelling er niet is, zal de verplichte winstbepaling resulteren in een toename van de administratieve lasten voor bosbouwbedrijven. De behandeling van een reguliere aangifte met een bos- en/of natuurvrijstelling leidt in het algemeen tot beperkte uitvoeringskosten voor de overheid. De bosbouwvrijstelling bevat geen heldere definitie van bos. Door jurisprudentie heeft het begrip een brede betekenis gekregen. Ter oplossing van problemen bij de beoordeling van de toepassing is te denken aan een bosdefinitie met een kwantitatief criterium zoals minimaal 1 ha bos.

\section{Vrijstelling voor vergoedingen in bos- en natuurbeheer}

De vrijstelling vergoeding bos- en natuurbeheer is een objectieve vrijstelling in de inkomstenbelasting (IB) en vennootschapsbelasting (VPB) voor aangewezen subsidieregelingen ten behoeve van de ontwikkeling en instandhouding van bos en natuur. De belangrijkste subsidies in dit verband zijn de investeringssubsidie en de subsidie functieverandering onder de Subsidieregeling Kwaliteitsimpuls Natuur en Landschap (SKNL). Belastingplichtigen met bossen of natuurterreinen als ondernemingsvermogen (IB of VPB) of bezittingen waarop het regime van het resultaat uit een werkzaamheid van toepassing is, kunnen gebruik maken van de vrijstelling. Voor de doelgroep brengt de vrijstelling geen bijzondere administratieve lasten met zich mee. Door respondenten is gewezen op problemen in de uitvoeringspraktijk, zoals onterechte claims en correcties bij niet-vrijgestelde subsidies. De ontwikkeling en instandhouding van bos en natuurterreinen is vooral afhankelijk van de beschikbare subsidies, waarbij de fiscale vrijstelling een aanvullende betekenis heeft. Dit geldt vooral voor de functieverandering van landbouwgrond naar natuur in bepaalde gebieden, waarbij grote bedragen gemoeid zijn om het vermogensverlies te compenseren. 


\section{Vrijstelling bos- en natuurterreinen bij voordeel uit sparen en beleggen}

De vrijstelling bos- en natuurterreinen bij voordeel uit sparen en beleggen houdt in dat particulieren de waarde van hun betreffende bezit niet aangeven in box 3 van de inkomstenbelasting. De vrijstelling is goed bekend bij de doelgroep. Voor zover ze niet kwalificeren als ondernemer, wordt de vrijstelling gebruikt door alle particulieren met volle eigendom van bos, natuurterreinen en landgoederen, gerangschikt onder Natuurschoonwet 1928 (NSW). De vrijstelling draagt bij aan de aantrekkelijkheid van het particuliere bezit van bos en natuur. Er zijn vraagtekens geplaatst bij de uitsluiting van bloot eigenaren en vruchtgebruikers. Het budgettaire belang van de vrijstelling is in de Miljoenennota 2016 geschat op 6 miljoen euro per jaar. Een alternatief voor de vrijstelling is een verhoging van subsidies, wat naar verwachting gepaard gaat met hogere uitvoeringskosten. Zonder de vrijstelling zou het particuliere vermogen in bos- en natuurterreinen jaarlijks gewaardeerd moeten worden. Door forfaitaire bepaling kunnen de kosten hiervan evenwel laag worden gehouden.

\section{Vrijstelling overdrachtsbelasting natuurgronden}

De vrijstelling overdrachtsbelasting natuurgronden stelt verkrijgers van natuurgronden vrij van overdrachtsbelasting. Deze vrijstelling is in 2008 geïntroduceerd als aanvulling op andere vrijstellingen van overdrachtsbelasting bij natuur. De perceptie van de praktijk is dat de doelgroep in een redelijke/voldoende mate wordt bereikt. Vanwege overlappende regelingen wordt aan de vrijstelling geen grote impact toegekend op het behoud en de toename van natuur door niet-overheden. Het budgettaire belang van de vrijstelling wordt in de Miljoenennota geschat op 3 miljoen euro per jaar. Voor de doelgroep zijn de administratieve lasten te verwaarlozen. De notaris verzorgt de aangifte overdrachtsbelasting bij de aanbieding ter registratie van de akte van levering. De controle van de Belastingdienst valt binnen de normale aangiftebehandeling. Verder zal de Belastingdienst de tienjaarstermijn controleren. Al met al worden de uitvoeringskosten van de overheid als klein beschouwd.

\section{WILG-vrijstelling}

De vrijstelling overdrachtsbelasting WILG (Wet Inrichting Landelijk Gebied) is een in de praktijk gewaardeerd middel om de structuurverbetering van het landelijk gebied te helpen realiseren. De vrijstelling bevordert de structuurverbetering door de aankoop en ruil van gronden te faciliteren (i.e. herverkaveling en kavelruil). Dit maakt het eenvoudiger om wegen, waterlopen en overige infrastructuur aan te leggen en gronden van eigenaren kunnen zo dichter bij elkaar worden gebracht. De administratieve lasten voor de doelgroep zijn gering: het beroep op de vrijstelling wordt gedaan in de notariële akte. De uitvoeringskosten van de overheid zijn ook gering. Het budgettaire belang van de vrijstelling wordt vermoedelijk onderschat, omdat de waarden van de achterliggende transacties niet worden vastgelegd. Voor een beroep op de vrijstelling voor kavelruil geldt geen inhoudelijk toetsingskader. Hierdoor is het mogelijk dat de vrijstelling door partijen wordt gebruikt die op het fiscale voordeel uit zijn zonder structuurverbetering te realiseren. Bij eventuele inperking van de doelgroep, verdient het aanbeveling om de maatschappelijk gewenste kavelruil niet te belemmeren.

\section{$B B L-v$ rijstelling}

De BBL-vrijstelling (Bureau Beheer Landbouwgronden) is een subjectieve en generieke vrijstelling van overdrachtsbelasting voor verkrijgingen in het kader van het overheidsbeleid. Van oudsher heeft de vrijstelling bijgedragen aan de structuurverbetering van het landelijk gebied. De vrijstelling sluit geheel aan op de behoefte van BBL. Het budgettaire belang van de vrijstelling heeft jarenlang boven 10 miljoen euro gelegen, maar door vermindering van activiteiten neemt dit belang snel af. De administratieve lasten voor de doelgroep zijn beperkt tot het beroep op de vrijstelling in de notariële akte. De uitvoeringskosten van de overheid zijn ook zeer gering. Na opheffing BBL blijft er behoefte aan gronden als smeerolie voor landinrichting. Vrijstellingen voor grondbanken en andere vergelijkbare instanties kunnen wenselijk zijn om de grondmobiliteit op een gewenst niveau te kunnen houden. 


\section{S.2 Vraagstelling en methode}

Deze evaluatie door Wageningen Economic Research is gericht op de doeltreffendheid en doelmatigheid van zes fiscale vrijstellingen voor bos en natuur in de periode 2010-2015. Het onderzoek is uitgevoerd in opdracht van het ministerie van Economische Zaken. Gegevens over gebruik en effecten van deze fiscale vrijstellingen op het gebied van bos en natuur zijn slechts beperkt vastgelegd. Binnen het brede instrumentarium van het bos- en natuurbeleid gaat het om betrekkelijk kleine faciliteiten in budgettair opzicht. Het is in dit onderzoek niet mogelijk gebleken om de effecten van de vrijstellingen te kwantificeren. De evaluatie heeft dan ook vooral een kwalitatief karakter. In de eerste stap zijn reconstructies van de beleidstheorie van de vrijstellingen samengesteld. Vervolgens zijn gegevens en ervaringen met de uitvoering verzameld. Voor de onderbouwing van de doeltreffendheid en doelmatigheid zijn interviews gehouden met verschillende groepen betrokkenen. Hiermee is inzicht verkregen in de wijze waarop stakeholders de werking en effecten van de vrijstellingen beoordelen. 


\section{Summary}

\section{S.1 Key findings}

\section{General}

Tax exemptions have a supporting role in Dutch forest and nature conservation policy. The exemption for income from forestry activities contributes to forest management by businesses. The exemption for payments relating to forest and nature conservation ensures that the grants and subsidies concerned can be kept lower while still achieving the same effects. The exemption of nature in the case of income from savings and investments contributes to the attractiveness of the private ownership of forests and other areas of nature. Besides these three exemptions from income tax, there are also exemptions from transfer tax. The exemption from transfer tax on natural, uncultivated areas promotes the attractiveness of nature as an investment opportunity. The exemption from transfer tax under the Rural Areas (Planning) Act (WILG) contributes to the structural improvements to rural areas. This has traditionally also applied to the Land Management Service (Bureau Beheer Landbouwgronden, BBL) exemption. The six exemptions mentioned are well known to and attractive for the various target groups, particularly in relation to the administrative burdens. The implementation costs for the government are also low. This evaluation further addresses the effectiveness and efficiency of the exemptions.

\section{Exemption for income from forestry activities}

The exemption for income from forestry activities is an objective exemption that determines that the profit of the forestry company is not taxed. The exemption applies to every entrepreneur/business that utilises the forest. On the other hand, if the expenses of the forestry company exceed the income, the negative balance cannot be deducted from income gained elsewhere. Almost all forestry companies make use of this, as do a number of other businesses. The share option scheme, which was established in order to be able to opt for the taxed regime, is barely used. It is likely that the exemption contributes to forest management by businesses, but it is not possible to determine to what extent it contributes to the conservation of the forested area. The budgetary importance is estimated in the Budget Statements for 2012-2016 (Miljoenennota's 2012-2016) at one million euros per year. Against the backdrop of the increased operating results of private forestry in recent years, this is probably an underestimation of the actual importance. Insofar as the exemption for income from forestry activities is applicable, no determination of the profit of the forestry company is necessary. If the exemption does not apply, the compulsory determination of profit will result in an increase in the administrative burdens for forestry companies. The handling of a standard tax return with a forestry or nature conservation exemption generally leads to limited implementation costs for the government. The forestry exemption comprises no clear definition of 'forest'. It has been through case law that the concept has gained a broad meaning. Possible solutions for problems in the assessment of the application could include a definition of forests with a quantitative criterion, such as a minimum of one hectare of forest.

\section{Exemption for payments in forest management and nature conservation}

The exemption for payments in forest management and nature conservation is an objective exemption in income tax and corporation tax for designated grant and subsidy schemes for the benefit of the development and conservation of forests and other areas of nature. The most important grants and subsidies in this regard are the investment subsidy and the function change subsidy within the national quality incentive for nature and landscape (Subsidieregeling Kwaliteitsimpuls Natuur en Landschap, SKNL). Taxpayers with forests or nature areas as business assets (income tax or corporation tax) or possessions to which the regime of the results from an activity apply can make use of the exemption. For the target group, the exemption is not accompanied by any administrative burdens of particular note. Respondents have pointed to problems in practice during implementation, such as unjust claims and corrections for non-exempt subsidies. The development and conservation of forests and nature areas is primarily dependent on the available subsidies, whereby the tax exemption has additional significance. This applies particularly to the change of function of agricultural land to nature in certain areas, involving large sums to compensate for the loss of assets. 
Exemption of forests and other nature areas in the case of income from savings and investments The exemption of forests and other nature areas in the case of income from savings and investments means that private individuals cannot state the value of the possession concerned in 'box 3' of their income tax return (relating to taxable income from savings and investments). The exemption is well known to the target group. As long as they do not qualify as an entrepreneur, the exemption is used by all private individuals with full ownership of forest, nature areas, and country estates, ranked under the Estates Act 1928 (Natuurschoonwet 1928, NSW). The exemption contributes to the attractiveness of the private ownership of forests and other areas of nature. Questions have been raised regarding the exclusion of bare owners and usufructuaries. The budgetary importance of the exemption is estimated in the Budget Statement for 2016 (Miljoenennota 2016) at six million euros per year. An alternative to the exemption is an increase in the level of grants and subsidies, which would be expected to be linked with higher implementation costs. Without the exemption, the private capital in forests and nature areas would need to be valued annually. Through flat-rate determinations, the costs of this can also be kept low.

\section{Exemption from transfer tax relating to natural, uncultivated areas}

The exemption from transfer tax relating to natural, uncultivated areas allows the acquisition of natural areas free of transfer tax. This exemption was introduced in 2008 as a supplement to other exemptions from transfer tax for nature. The perception of how it works in practice is that the target group is reached to a reasonable/adequate extent. Due to overlapping regulations and schemes, the exemption is not considered by non-governmental bodies to have a major impact on the conservation of or increase in nature.

The budgetary importance of the exemption is estimated in the Budget Statement (Miljoenennota) at three million euros per year. For the target group, the administrative burdens are minimal. The civillaw notary takes care of the tax declaration for transfer tax when submitting the deed of transfer of title for registration. The checks by the Dutch tax authorities (Belastingdienst) form part of the standard handling of tax returns. The Dutch tax authorities also check the ten-year term. All in all, the implementation costs for the government are considered low.

\section{WILG exemption}

In practice, the exemption from transfer tax under the Rural Areas (Planning) Act (WILG) is a valued tool in helping to bring about structural improvement in rural areas. The exemption promotes the structural improvement by facilitating the purchase and exchange of land (i.e. the reallotment of land and plot exchange). This makes it simpler to construct roads, watercourses and other infrastructure, and owners' sections of land can be brought closer together. The administrative burdens for the target group are minimal: the invocation of the exemption takes place via the notarial deed. The implementation costs for the government are also low. The budgetary importance of the exemption has probably been underestimated, as the values of the underlying transactions are not recorded. No substantive assessment framework applies to claims for exemption relating to plot exchange. This makes it possible for the exemption to be used by parties that are looking for a tax advantage without actually making any structural improvements. If the target group were to be restricted, the recommendation would be not to obstruct the socially-desirable plot exchange.

\section{Land Management Service (BBL) exemption}

The Land Management Service (BBL) exemption is a subjective and generic exemption from transfer tax on acquisitions within the framework of government policy. Traditionally, the exemption has contributed to structural improvements in rural areas. The exemption is fully in line with the needs of the Land Management Service. The budgetary importance of the exemption was more than ten million euros for several years; however, due to a reduction in the number of activities, this sum is rapidly declining. The administrative burdens for the target group are limited to the invocation of the exemption via the notarial deed. The implementation costs for the government are also very low. Following the closure of the Land Management Service, there will still be a need for land as the 'lubricant' for land use determination. Exemptions for land banks and other similar organisations could be desirable in order to keep land mobility at the desired level. 


\section{S.2 Research question and method}

This evaluation by Wageningen Economic Research focuses on the effectiveness and efficiency of six tax exemptions for forests and other nature areas in the period 2010-2015. This study was commissioned by the Dutch Ministry of Economic Affairs. Only limited data has been recorded on the use and effects of these tax exemptions in the field of forests and nature areas. Within the broad set of instruments of forestry and nature policy, in budgetary terms these are relatively small-scale facilities. It turned out not to be possible in this study to quantify the effects of the exemptions. The evaluation is therefore primarily qualitative in character. In the first step, reconstructions were drawn up of the policy theory of the exemptions. Next, data and experiences with the implementation were collected. To provide a solid basis for the effectiveness and efficiency, interviews were held with various groups. In this way, insight was gained into the way in which stakeholders assess the workings and effects of the exemptions. 


\section{$1 \quad$ Inleiding}

\section{$1.1 \quad$ Aanleiding}

In de Rijksbegroting $2015^{1}$ is de evaluatie gepland van zes fiscale vrijstellingen op het gebied van bos en natuur. Alle belastinguitgaven dienen in principe iedere vijf jaar geëvalueerd te worden. In het kader van het Beleidsondersteunend Onderzoek heeft het ministerie van EZ aan Wageningen Economic Research opdracht verleend om de zes vrijstellingen te evalueren (tabel 1.1).

Tabel 1.1 Zes fiscale vrijstellingen op het gebied van bos en natuur

\begin{tabular}{|c|c|}
\hline Regeling & Vrijstelling \\
\hline 1.Bosbouwvrijstelling & Winst IB \& VPB a) \\
\hline 2.Vrijstelling vergoeding bos- en natuurbeheer & Winst IB \& VPB \\
\hline 4.Vrijstelling overdrachtsbelasting natuurgrond & Overdrachtsbelasting \\
\hline 5.Vrijstelling overdrachtsbelasting Wet Inrichting Landelijk Gebied (WILG) & Overdrachtsbelasting \\
\hline
\end{tabular}

a) IB: Inkomstenbelasting; VPB: Vennootschapsbelasting.

Het natuurbeleid van het Rijk dient twee strategische doelen: duurzame benutting van natuur, en behoud van biodiversiteit (zie beleidsdoorlichting begrotingsartikel 18 ). ${ }^{2}$ Deze doelen vormen het overkoepelend kader voor de zes fiscale vrijstellingen. Daarbinnen gelden specifieke beleidsdoelen.

\subsection{Doel en afbakening}

Het doel van dit onderzoek is inzicht te geven in de doeltreffendheid en doelmatigheid van de zes bovengenoemde fiscale vrijstellingen. Het ministerie van Economische Zaken zal de Tweede Kamer hierover informeren. De fiscale vrijstellingen maken deel uit van een breed instrumentarium van de overheid voor het natuurbeleid.

Hoewel BBL per 2020 wordt beëindigd, is de betreffende vrijstelling in deze evaluatie bewust meegenomen. Omdat provincies straks gebruik zullen maken van een ander grondbedrijf, is inzicht gewenst in de doeltreffendheid en doelmatigheid van dit instrument voor het realiseren van landinrichtingsprojecten.

De evaluatie heeft betrekking op de periode 2010-2015. Gegevens over gebruik en effecten van deze fiscale vrijstellingen op het gebied van bos en natuur zijn slechts beperkt beschikbaar. Om deze reden heeft de evaluatie vooral een kwalitatief karakter; waar mogelijk worden de conclusies kwantitatief onderbouwd.

\footnotetext{
1 Miljoenennota 2015, Hoofdstuk 12. Toelichting op de belastinguitgaven. www.rijksbegroting.nl/2015/kamerstukken,2014/9/19/kst812061_4.html

2 Brief van de staatssecretaris van Economische Zaken (24 december 2015): Tweede Kamer, vergaderjaar 2015-2016, 30 991, nr. 29
} 


\subsection{Onderzoeksvragen}

Om de doeltreffendheid (effectiviteit) en doelmatigheid (efficiëntie) van de vrijstellingen te kunnen bepalen, dienen de volgende vragen te worden beantwoord:

Doeltreffendheid:

- In welke mate wordt de relevante doelgroep bereikt?

- Sluit de vrijstelling aan bij de behoefte van de doelgroep?

- In welke mate draagt de vrijstelling bij aan het bereiken van het doel van het beleid?

Doelmatigheid:

- Wat is het budgettair belang van de vrijstelling?

- Zijn er alternatieven voor de vrijstelling? Zo ja, kunnen die het doel van het beleid met minder kosten realiseren?

- Wat is de samenhang/overlap van de vrijstelling met andere regelingen?

- Wat zijn de administratieve lasten van de vrijstelling voor de doelgroep?

- Wat zijn de uitvoeringskosten van de vrijstelling voor de overheid?

- Zijn er andere bijzonderheden in de praktijk?

\section{$1.4 \quad$ Methode}

Het onderzoek voor de beantwoording van de vragen is als volgt opgebouwd:

\section{Stap 1: Reconstructie beleidstheorie}

In deze eerste stap zijn voorlopige reconstructies van de beleidstheorie van de vrijstellingen samengesteld. Om de reconstructies op te zetten en aan te scherpen zijn beleidsdocumenten en beleidsmedewerkers geraadpleegd, zowel bij het ministerie van Economische Zaken als bij het ministerie van Financiën en de Belastingdienst. Ook is bestaand bronmateriaal geanalyseerd. Hierbij gaat het om de geschiedenis van de wetgeving, eerdere evaluaties, onderzoeksrapporten, databases en jaarverslagen. Ook is er gezocht naar relevante feiten en mechanismen die betrekking hebben op de werking van de vrijstellingen. Daarmee is inzichtelijk gemaakt hoe het beleid eruit heeft gezien (in termen van doelen, instrumenten en beoogde effecten) en op welke veronderstellingen en overtuigingen het beleid is gebaseerd. Naar aanleiding hiervan zijn vragen geformuleerd voor de volgende stappen.

Stap 2: Verzamelen en analyseren van gegevens en ervaringen met de uitvoering Behalve de indicaties van het budgettair belang in de Miljoenennota, zijn er niet direct openbare gegevens voorhanden over de benutting van de vrijstellingen. Waar mogelijk is informatie verzameld uit openbare bronnen en bij de Belastingdienst. Daarbij is ook gevraagd naar de uitvoeringspraktijk en de daarmee samenhangende kosten.

\section{Stap 3: Perceptieonderzoek onder stakeholders}

Voor de onderbouwing van de effectiviteit is geen econometrische analyse uitgevoerd, maar is een pragmatische aanpak gevolgd. Er zijn interviews gehouden met verschillende groepen betrokkenen (bijlage 1). Hiermee is inzicht verkregen in de wijze waarop stakeholders de werking en effecten van de vrijstellingen beoordelen. Ook is gevraagd naar de betekenis van de vrijstellingen in de praktijk en of er knelpunten worden ervaren.

Voor deze aanpak is gekozen omdat er voor de beoordeling van de zes fiscale vrijstellingen weinig harde gegevens beschikbaar zijn. Zo zijn geen nulmetingen uitgevoerd, wat het bijzonder moeilijk maakt om de effecten van de vrijstellingen te bepalen. De bosbouwvrijstelling, de vrijstelling vergoeding bos- en natuurbeheer en de vrijstelling forfaitair rendement waren onderdeel van het rapport Fiscale faciliteiten en knelpunten bij natuurontwikkeling door particulieren uit $2005 .{ }^{3}$ De

3 http://edepot.wur.nl/31601 
vrijstellingen overdrachtsbelasting WILG en BBL waren onderdeel van de evaluatie in 2008 van vrijstellingen voor de landbouw. ${ }^{4}$ De vrijstelling van natuurgrond bestaat sinds 2008.

Een bijkomende reden voor de gekozen aanpak heeft te maken met controlegroepen. Zonder controlegroepen is wetenschappelijk niet vast te stellen of en in hoeverre een regeling effectief is. Voor de Bosbouwvrijstelling bestaat de optieregeling waarbij schriftelijk kan worden verzocht om de vrijstelling niet van toepassing te doen zijn. Deze laatste groep kan interessante informatie opleveren maar is geen zuivere controlegroep. Voor de beoordeling van de overige fiscale vrijstellingen zijn evenmin controlegroepen voorhanden.

Stap 4: Analyse

In deze stap is de verzamelde informatie per vrijstelling geanalyseerd. Hierdoor zijn beelden gevormd van het gevoerde beleid en hoe die beelden zich verhouden tot wat werd beoogd.

Stap 5: Synthese

De bevindingen van de voorafgaande stappen zijn vastgelegd in de hoofdstukken 2 tot en met 7 van dit rapport. 


\section{Bosbouwvrijstelling}

\section{$2.1 \quad$ Beleidstheorie}

\section{Inhoud}

De bosbouwvrijstelling is een fiscale faciliteit in de inkomstenbelasting (IB) voor ondernemers met een bosbedrijf. De vrijstelling is vastgelegd in artikel 3.11 van de Wet IB 2001; via de schakelbepaling van artikel 8, eerste lid, van de Wet Vpb 1969, is de vrijstelling ook van toepassing op ondernemingen die belastingplichtig zijn voor de vennootschapsbelasting. Het is een objectieve vrijstelling die bepaalt dat alle voordelen uit het bosbedrijf niet tot de winst behoren. De vrijstelling geldt voor iedere ondernemer/onderneming die bos exploiteert, ook al maakt die exploitatie slechts een klein deel uit van een onderneming met geheel andere activiteiten.

Voordelen uit het bosbedrijf worden niet tot de winst gerekend. Het begrip 'voordelen' heeft betrekking op het saldo van baten en lasten. Nagegaan moet worden welke kosten en opbrengsten enerzijds aan het bosbedrijf moeten/kunnen worden toegerekend en anderzijds aan de overige onderneming. Als de lasten van het bosbedrijf de baten overtreffen is het negatieve saldo niet aftrekbaar van elders genoten inkomsten: de bosbouwvrijstelling werkt dan in het nadeel van de ondernemer.

Voordelen uit het bosbedrijf bestaan uit directe en indirecte opbrengsten, nevenopbrengsten en vervreemdingsvoordelen:

- directe opbrengsten onder andere boshout, waardeverandering ondergrond

- indirecte opbrengsten onder andere huurinkomsten boswachterswoning, verkoopopbrengst wandelkaarten, subsidies SNL (bevordering bos in landbouwgebied), jachthuur, recreatie

- nevenopbrengsten opbrengst mos, bosbessen, zaden enzovoort die oorsprong hebben in de biologische gemeenschap van opstand en bodem

- vervreemdingsvoordelen bestemmingswijzigingswinst bij verkoop grond is wel belast.

De bosbouwvrijstelling bestaat sinds 1926 en is vrijwel ongewijzigd in de Wet IB 1964 overgenomen. De belangrijkste wijzigingen die later in de wet zijn aangebracht:

\section{- 1994} snelgroeiend bos (hakhout) valt ook onder het bosbegrip voor de bosbouwvrijstelling, mits voldaan wordt aan de instandhoudingseis (Kamerstukken II 1993/94, 23 176, nr. 3, p. 1.).

- 2001 uitbreiding vrijstelling tot buitenlands bosbedrijf.

\section{Optieregeling}

De bosbouwer kan de belastinginspecteur schriftelijk verzoeken om de bosbouwvrijstelling niet van toepassing te doen zijn. Deze optie is opgenomen in artikel 11a van het Uitvoeringsbesluit inkomstenbelasting 2011. Indien de inspecteur akkoord gaat, dan geldt dit tot wederopzegging, maar ten minste voor 10 jaren. Met deze optieregeling komen de voor- en nadelen uit het bosbedrijf onder het normale fiscale regime van de IB/VPB. De resultaten van het bosbedrijf zijn dan te verrekenen met buiten de bosbouw geboekte resultaten. Van de optieregeling kan in beginsel alleen gebruik worden gemaakt indien het bosbedrijf gezien kan worden als een onderneming.

\section{Beoogde doelgroep}

De beoogde doelgroep bestaat uit grondeigenaren die de bosbouw (bedrijfsmatig) beoefenen en alles wat daarmee rechtstreeks verband houdt. De vrijstelling staat open voor de ondernemer (art. 3.4 Wet 
IB 2001) en de medegerechtigde (art. 3.3 Wet IB 2001). ${ }^{5}$ Door de werking van art. 3.95 Wet IB 2001 kan een resultaatgenieter ${ }^{6}$ geen beroep doen op de bosbouwvrijstelling (Van Es, 2014).

\section{Beoogde effecten}

Het doel van de vrijstelling is een bijdrage te leveren aan de instandhouding en ontwikkeling van bos (figuur 2.1). Bossen worden in Nederland veelal gezien als een publiek belang dat bescherming verdient. Ter bewaring van bossen en andere houtopstanden is er de Boswet, die voorwaarden stelt aan het vellen van houtopstanden en herbeplanting voorschrijft. Daarnaast worden diverse subsidies verstrekt voor de ontwikkeling en instandhouding van bos. ${ }^{7}$ De bosbouwvrijstelling leidt ertoe dat de resultaten van de bosbouw niet worden belast.

In de parlementaire geschiedenis is de wens weergegeven om de opbrengst van bossen aan de inkomstenbelasting te onttrekken. Hiervoor zijn indertijd twee redenen aangevoerd (Niessen, 2013).

- De eerste reden is gelegen in de moeilijkheden met betrekking tot de (jaarlijkse) winstbepaling van bosbedrijven (Handelingen II 1919/20 21 april 1920, p. 1895).

- De tweede reden is te vinden in het 'groot algemeen belang' dat gelegen is 'in het bezit van een goeden boschstand' (Kamerstukken II 1925/26, 266, nr. 3, p. 1-2).

Bij de wetswijziging van 1994 is opgemerkt: 'Deze vrijstelling beoogt het bosbestand in Nederland te bevorderen. [...] In samenhang met [...] wordt daarmee een bijdrage geleverd aan het behoud en aanleg van bossen', Parlementaire behandeling. Wet van 24 juni 1994, Stb. 1994, 497 (Geciteerd door Schenk en Seegers, 2013: p. 8).

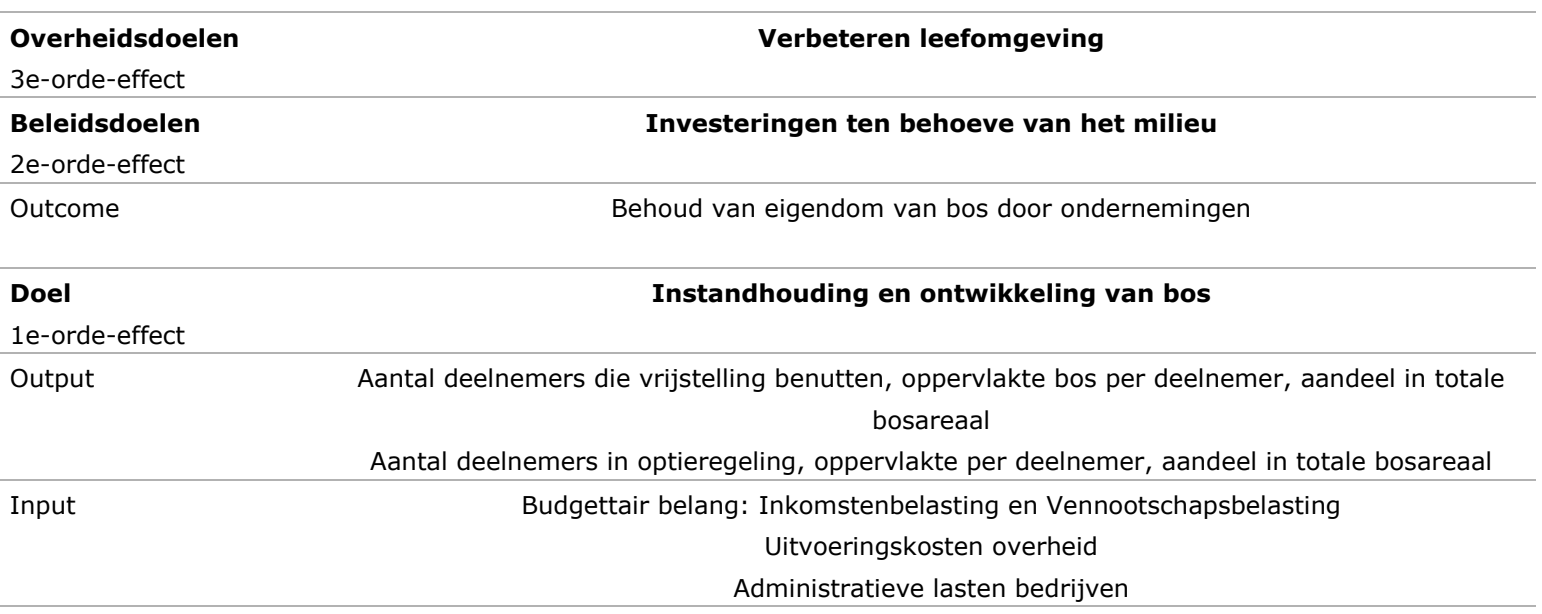

Figuur 2.1 Doelenboom van de bosbouwvrijstelling

\subsection{Doeltreffendheid}

\section{Doelgroep}

De bosbouwvrijstelling heeft een lange geschiedenis en is algemeen bekend bij de doelgroep. Op grond van de interviews (bijlage 1) kan worden gesteld dat de bosbouwvrijstelling alle eigenaren met een substantieel areaal aan bos bereikt; eigenaren met slechts enkele hectaren bos kwalificeren veelal niet als ondernemer en maken gebruik van de box 3 vrijstelling (zie hoofdstuk 4). Ook andere bedrijven (landbouwbedrijven) maken voor een deel van hun omzet wel gebruik van de bosbouwvrijstelling, maar het aantal is niet bekend, noch het areaal dat daarmee gemoeid is.

\footnotetext{
5 De medegerechtigde is een belastingplichtige die - anders dan als ondernemer of aandeelhouder - gerechtigd is tot het vermogen van een onderneming, en die daaruit winst geniet.

6 Resultaatgenieters zijn geen ondernemer voor de inkomstenbelasting.

7 Subsidiestelsel Natuur en Landschap (SNL), opvolger van de Provinciale Subsidieregeling Natuurbeheer (PSN) onder Programma Beheer.
} 
Voor de doelgroep sluit de bosbouwvrijstelling aan op de behoefte vanwege de besparing op administratieve lasten. De opbrengst van het bos is vaak 'bijvangst' waarvan het maar de vraag is of daarvan een aparte administratie wordt bijgehouden. Voor het bosbedrijf is winstbepaling niet nodig, zodat eventuele discussies over vaststellen en toerekenen van kosten, waardering, kapitaal en voorraad achterwege kunnen blijven. Dit laatste geldt niet voor ondernemingen die ook andere activiteiten verrichten, omdat er dan een splitsing van de boekhouding moet plaatsvinden (om de resultaten te kunnen splitsen dienen de opbrengsten en kosten van de activiteiten te worden onderscheiden).

\section{Gebruik van optieregeling}

Van de optieregeling (zie paragraaf 2.1) wordt niet (of nauwelijks) gebruik gemaakt. In gesprekken met rentmeesters en accountants (zie bijlage 1 ) is slechts één bedrijf naar voren gekomen dat opteerde voor het belaste regime; inmiddels is dat bedrijf weer naar de bosbouwvrijstelling teruggekeerd. Het is niet bekend of andere bedrijven opteren of geopteerd hebben voor het belaste regime.

\section{Bijdrage aan overheidsbeleid}

Volgens de respondenten draagt de bosbouwvrijstelling zonder meer bij aan de instandhouding van bos, wat met de regeling wordt beoogd. Dankzij de bosbouwvrijstelling is de eventuele winst na belasting hoger dan zonder de vrijstelling. Volgens de respondenten heeft dit de investeringen in het bosbeheer bevorderd. Omdat een controlegroep ontbreekt, kan niet worden vastgesteld of en in welke mate dat het geval is geweest.

\subsection{Doelmatigheid}

\section{Budgettair belang}

Volgens de Miljoenennota's is het budgettaire belang van de bosbouwvrijstelling de afgelopen jaren 1 miljoen euro per jaar (tabel 2.1).

Tabel 2.1 Budgettair belang (miljoen euro) bosbouwvrijstelling, 2010-2015

\begin{tabular}{lrrrrrrr} 
& 2010 & 2011 & 2012 & 2013 & 2014 & 2015 \\
Budgettair belang & 1 & 1 & 1 & 1 & 1 \\
\hline
\end{tabular}

Bronnen: Miljoenennota 2012-2016.

Vanaf 2010 is de belastingaangifte sterk gecomprimeerd (minder rubrieken) met als doel een administratieve lastenverlichting. De bosbouwvrijstelling is in de aangifte opgenomen in één rubriek samen met de landbouwvrijstelling. Hierdoor is geen specificatie mogelijk van het belang van de bosbouwvrijstelling en optieregeling.

In de Miljoenennota van 2005 werd het budgettaire belang van de bosbouwvrijstelling bepaald op 2 miljoen euro. Het verlaagde bedrag $(1 \mathrm{mln}$. euro) komt overeen met de schatting van het LEI in 2005 (Boers et al., 2005). Het LEI-rapport stelt dat er met betrekking tot de bosbouwvrijstelling niet of nauwelijks sprake is van belastinguitgaven voor het Rijk omdat de gemiddelde inkomensvorming op de meeste bedrijven negatief is. Voor zover de bedrijven wel een positief resultaat halen, komt dat volgens het rapport vooral door opbrengsten uit subsidies die zijn vrijgesteld van belasting.

Intussen is de situatie in de bosbouw zodanig gewijzigd dat het werkelijke budgettaire belang van de bosbouwvrijstelling vermoedelijk is toegenomen. De bedrijfsuitkomsten van de bosbouw hebben de afgelopen jaren namelijk een positieve ontwikkeling laten zien. Vanaf 2006 zijn vooral door de stijging van de houtprijzen de meeste jaren met een plus afgesloten. In de periode 2009-2013 is een positief resultaat behaald van gemiddeld 13 euro per ha per jaar, tegenover een verlies van 64 euro per ha per jaar in de periode 2001-2005. Het gemiddelde inkomen uit het bosbedrijf - dat is het 
bedrijfsresultaat zonder de berekende arbeidskosten (in hoofdzaak van de eigenaar) in mindering te brengen - is voor 2013 becijferd op 67 euro per ha (zie ook bijlage 2).

\section{Andere regelingen}

De bosbouwvrijstelling staat niet los van andere beleidsmaatregelen. Dat zijn zowel stimulerende maatregelen, zoals andere fiscale vrijstellingen en vergoedingen (subsidies) voor bos en natuur, evenals beschermende (verbods)maatregelen neergelegd in bijvoorbeeld de Boswet en ruimtelijke ordening (bestemmingsplan). De herplantplicht van de Boswet voorkomt dat kaalslag plaatsvindt. Met de subsidies voor instandhouding en ontwikkeling van bos wordt op de kwaliteit van het bosbeheer gestuurd. De subsidie voor het reguliere beheer loopt geleidelijk terug. Dat heeft te maken met de overgang van de Provinciale Subsidieregeling Natuurbeheer (PSN) als onderdeel van het Programma Beheer naar het Subsidiestelsel Natuur en Landschap (SNL). De beheersubsidie voor productiebos is in de nieuwe regeling veel lager dan in de oude. Dit heeft een drukkend effect op de rentabiliteit van de houtproductie.

\section{Administratieve lasten}

Eén van de historische argumenten voor de bosbouwvrijstelling is dat de winstbepaling lastig is. Voor zover de bosbouwvrijstelling van toepassing is, is het bepalen van de winst van het bosbedrijf niet nodig. De vrijstelling levert voor het bosbedrijf dan ook een voordeel in administratieve lasten op. Er kunnen duidelijke regels voor de winstbepaling worden voorgeschreven op basis van het realisatiebeginsel (Van Es, 2015), maar die voorkomen de problemen niet bij de noodzakelijke waardering van de biologische activa (hout en bosopstanden). Wanneer de vrijstelling er niet is, zal de verplichte winstbepaling resulteren in een toename van de administratieve lasten voor bosbouwbedrijven.

\section{Uitvoeringskosten overheid}

De beoordeling op juistheid van de toepassing van de bosvrijstelling is onderdeel van de reguliere aangiftebehandeling, waardoor de behandeling van een reguliere aangifte met een bos- en/of natuurvrijstelling in het algemeen tot beperkte uitvoeringskosten leidt.

\section{Bijzonderheden in de praktijk}

Het voorgaande geldt niet voor gevallen waarin de grenzen van de wet worden opgezocht, en de toepassing van de vrijstelling kan worden betwist. In de uitvoeringspraktijk komt de afbakeningsproblematiek incidenteel voor. De bosbouwvrijstelling bevat geen heldere definitie van bos. De regeling heeft in de jurisprudentie een ruimer toepassingsbereik gekregen dan oorspronkelijk is beoogd. De Hoge Raad besliste in het arrest van 6 december 2013 (ECLI:NL:HR:2013:1437, Hoge Raad, 12/02449) dat de bosbouwvrijstelling ook van toepassing is ingeval van snoeien van bomen in een bos voor verkoop van snijgroen. Hierdoor zijn de toepassingsmogelijkheden van de bosbouwvrijstelling verruimd. Indien bij de eigenaar het instand houden van het op zijn terrein staand opgaand hout op de voorgrond staat, kan worden gesproken van een bosbedrijf. Hieraan is voldaan indien niet méér wordt gekapt dan een normaal bosbeheer meebrengt en het kappen zo nodig door herbeplanting wordt gevolgd. Ter oplossing van problemen bij de beoordeling van de juiste toepassing valt te denken aan een definitie van bos met een kwantitatief criterium zoals minimaal 1 ha bos.

Met de invoering van de belastingplicht voor overheidsbedrijven (per 1 januari 2016) is de bosbouwvrijstelling intussen ook relevant voor gemeenten en Staatsbosbeheer. Staatsbosbeheer acht de bosbouwvrijstelling van groot belang voor de continuïteit van bos- en natuurbeheer in het algemeen en voor Staatsbosbeheer in het bijzonder. 


\section{$3 \quad$ Vrijstelling vergoeding bos- en natuurbeheer}

\subsection{Beleidstheorie}

\section{Inhoud}

De vrijstelling vergoeding bos- en natuurbeheer is vastgelegd in artikel 3.13, lid 1, onderdeel g van de Wet IB 2001. Het gaat om een objectieve vrijstelling in de inkomstenbelasting (IB) en vennootschapsbelasting (VPB) voor aangewezen subsidieregelingen ten behoeve van de ontwikkeling en instandhouding van bos en natuur (zie kader). Voor zover ze niet al onder de bosbouwvrijstelling vallen, zijn de betreffende subsidies van belastingheffing vrijgesteld. Inmiddels zijn veel van de genoemde overeenkomsten en regelingen uitgefaseerd. De beleidsmatig gezien belangrijkste subsidies voor de vrijstelling zijn de bij onderdeel g vermelde investeringssubsidie en subsidie functieverandering onder de Subsidieregeling Kwaliteitsimpuls Natuur en Landschap (SKNL).

Overeenkomsten en regelingen onder de vrijstelling vergoeding bos- en natuurbeheer (Uitvoeringsregeling IB 2001, art. 6, lid 1)

a. de Tijdelijke regeling particulier natuurbeheer zoals die luidde tot 1 januari 2000;

b. de Subsidieregeling natuurbeheer 2000 zoals die luidde tot 1 januari 2007;

c. de Subsidieregeling natuurbeheer van de onderscheiden provincies;

d. de Subsidieregeling agrarisch natuurbeheer zoals die luidde tot 1 januari 2007, voor zover betrekking hebbende op de landschapssubsidie, bedoeld in artikel 2, aanhef en onderdeel b, van die regeling;

e. de Subsidieregeling agrarisch natuurbeheer van de onderscheiden provincies, voor zover betrekking hebbende op de landschapssubsidie, bedoeld in artikel 2, eerste lid, aanhef en onderdeel b, van die regeling;

f. de Subsidieverordening natuur- en landschapsbeheer van de onderscheiden provincies, voor zover betrekking hebbende op de subsidie natuurbeheer, bedoeld in artikel 3.1 van die verordening, en de subsidie landschapsbeheer, bedoeld in artikel 5.1.1.1 van die verordening;

g. de Subsidieregeling kwaliteitsimpuls natuur en landschap van de onderscheiden provincies, voor zover betrekking hebbende op de investeringssubsidie, bedoeld in artikel 8, eerste, derde en vierde lid, van die regeling, en de subsidie functieverandering, bedoeld in artikel 15 van die regeling;

h. de overeenkomsten met het Bureau Beheer Landbouwgronden:

- $1^{\circ}$. met het door de Dienst Landelijk Gebied toegekende nummer: 005/9001 van 29 mei 1996;

- $2^{\circ}$. met het door de Dienst Landelijk Gebied toegekende nummer: 008/9001 van 30 mei 1996;

- $3^{\circ}$. met het door de Dienst Landelijk Gebied toegekende nummer: 004/9001 van 27 oktober 1997;

- $4^{\circ}$. met het door de Dienst Landelijk Gebied toegekende nummer: 003/9001 van 15 december 1997;

i. de beschikkingen van de Minister van Economische Zaken van 18 april 1998 met de beschikkingnummers kaderwet/pnb/01, kaderwet/pnb/02 en kaderwet/pnb/03.

De subsidies vergoeden de nettokosten van bestaand(e) bos/natuurterreinen of de inrichting van nieuwe bossen/natuurterreinen (en het daarmee gepaard gaande vermogensverlies op grond). Bij de aanvragers van de subsidie kan het bos- of natuurterrein voor de inkomstenbelasting kwalificeren als ondernemingsvermogen (box 1, afdeling 3.2: winst uit onderneming), vermogen waarop het resultaat uit een werkzaamheid van toepassing is (box 1, afdeling 3.4) of een bezit gehouden ter belegging (box 3). De subsidiebedragen zijn bepaald met als uitgangspunt dat daarover geen winstbelasting verschuldigd is. Zodoende resulteert de uitgekeerde subsidie per saldo in dezelfde netto bijdrage voor de ontvanger.

De subsidie functieverandering wordt, binnen de staatssteunregels, gegeven als vergoeding van de waardevermindering van de grond door de omvorming van landbouwgrond naar natuurgrond of de aanleg van een landschapsbeheertype op landbouwgrond. Om de waardevermindering te bepalen wordt de huidige waarde van de landbouwgrond getaxeerd. Voor de restwaarde als natuurgrond wordt aangenomen dat deze $15 \%$ is van de huidige waarde van de landbouwgrond. Het verschil in waarde 
(85\%) kan als subsidie worden uitbetaald. Met de beheerder wordt een kwalitatieve verplichting afgesloten om te zorgen dat het gewenste natuurdoel op het perceel niet wordt geschaad en/of deze grond niet weer landbouwkundig in gebruik wordt genomen. De provincie maakt elk jaar in het Openstellingsbesluit bekend hoeveel budget er beschikbaar is voor de projectsubsidies. Er kunnen aanvragen worden ingediend totdat het subsidieplafond is bereikt.

De vrijstelling geldt niet voor subsidies voor agrarisch natuurbeheer. Daar gaat het om gronden met als hoofdfunctie landbouw, zodat de beheerskosten - en daarmee ook de subsidie - tot het resultaat uit de onderneming of uit een werkzaamheid moet worden gerekend (zelden of nooit komt de subsidie voor agrarisch natuurbeheer voor box 3 in beeld). Deze subsidie vergoedt dienovereenkomstig de inkomstenderving ten gevolge van het agrarisch natuurbeheer.

\section{Beoogde doelgroep}

Beoogde doelgroep van de fiscale vrijstelling zijn ondernemers die de betreffende vergoedingen voor bos- en natuurbeheer aanvragen en ontvangen. Dit zijn ondernemers die bos of natuur aan willen leggen of beheren. Niet alle beheerders van bos- en natuurterreinen zijn onderworpen aan de inkomstenbelasting. Bij particulieren (niet-ondernemers) vallen de bezittingen in box 3, waardoor de vergoedingen niet belast zijn (zie Vrijstelling bos- en natuurterreinen: voordeel uit sparen en beleggen).

\section{Beoogde effecten}

Bescherming van natuur en bos geldt als een publiek belang. Voor instandhouding en ontwikkeling van bos en natuur worden bepaalde subsidies verleend aan eigenaren van bos of natuur, in wording of al bestaand. Dit betreft onder meer de vergoeding voor de waardedaling van grond bij omzetting van landbouwgrond naar natuurgrond. De vrijstelling beoogt bij te dragen aan de instandhouding en ontwikkeling van bos en natuur (figuur 3.1).

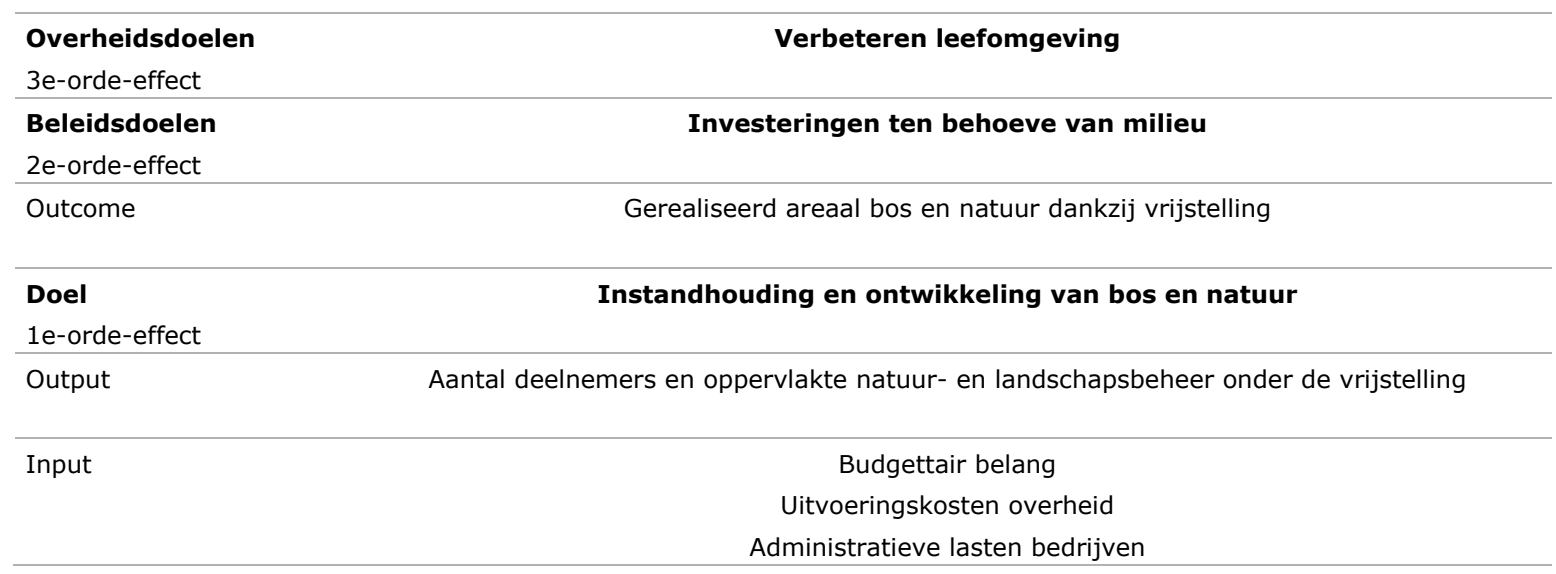

Figuur 3.1 Doelenboom van de vrijstelling vergoeding bos- en natuurbeheer

\subsection{Doeltreffendheid}

\section{Doelgroep}

Volgens de geraadpleegde personen (bijlage 1 ) is de vrijstelling voor vergoedingen in bos- en natuurbeheer algemeen bekend bij eigenaren die een beroep doen op de betreffende subsidieregelingen. In de subsidiebeschikking wordt gewezen op deze vrijstelling. De vrijstelling wordt benut door belastingplichtigen voor de inkomstenbelasting of vennootschapsbelasting met bossen of natuurterreinen als ondernemingsvermogen (IB of VPB) of bezittingen waarop het regime van het resultaat uit een werkzaamheid van toepassing is. De vrijstelling is niet relevant voor ontvangers voor wie het bos of natuurterrein in box 3 is vrijgesteld, noch voor stichtingen/verenigingen die buiten de belastingplicht vallen. 
Dankzij de vrijstelling van de subsidie in box 1 IB en in de VPB is het netto-effect bij de ontvanger onafhankelijk van de wijze waarop het bos of natuurterrein fiscaal gepositioneerd is. In box 3 wordt over de feitelijke inkomsten geen belasting geheven en voor de grondslag sparen en beleggen bestaat een vrijstelling voor bossen en natuurterreinen (zie hoofdstuk 4).

\section{Bijdrage aan overheidsbeleid}

De ontwikkeling en instandhouding van bos en natuurterreinen is vooral afhankelijk van de beschikbare subsidies. De fiscale vrijstelling heeft een aanvullende betekenis. De vrijstelling is hoofdzakelijk van belang om de functieverandering van landbouwgrond naar natuur in bepaalde gebieden te realiseren. Het areaal landbouwgrond in Nederland daalt, waarbij bebouwing de belangrijkste bestemming is. De landbouw heeft tussen 2000 en 2010 bijna 95.000 ha ingeleverd (zie ook bijlage 2). Hiervan is ruim 48.000 ha bestemd als bebouwd gebied, en ruim 25.000 ha voor recreatie, infrastructuur en water. Van de verminderde landbouwgrond is $22 \%$ omgezet in bos en natuur (CBS et al., 2014). Gezien de lagere waarde van bos- en natuurgrond (zie paragraaf 3.1) mag worden aangenomen dat dit met behulp van subsidies is gerealiseerd. Het aandeel hierin van de vrijgestelde subsidies voor ondernemers, is niet bekend.

\subsection{Doelmatigheid}

\section{Budgettair belang}

Tabel 3.1 vermeldt het budgettaire belang van de vrijstelling van natuursubsidies volgens de Miljoenennota's. Na jarenlang op 8 miljoen euro te zijn geschat, is het belang na 2013 afgenomen tot 6 miljoen euro in 2015. De daling houdt vermoedelijk verband met bezuinigingen op het natuurbeleid.


2010-2015

\begin{tabular}{lrrrrrrr} 
& 2010 & 2011 & 2012 & 2013 & 2014 \\
Budgettair belang & 8 & 8 & 8 & 6 & 7 \\
\hline
\end{tabular}

Bronnen: Miljoenennota 2012-2016.

\section{Administratieve lasten doelgroep}

Op zich brengt de vrijstelling voor de doelgroep geen noemenswaardige administratieve lasten met zich mee. Zoals gezegd wordt de vrijstelling vermeld in de subsidiebeschikking.

\section{Uitvoeringskosten overheid}

De uitvoeringskosten voor de overheid kunnen minimaal zijn. Daarbij is van belang dat de Belastingdienst wordt geïnformeerd over de verleende subsidies. Hierbij gaat het om het onderscheiden van de vrijgestelde vergoedingen voor bos- en natuurbeheer aan de ene kant en die voor agrarisch natuurbeheer aan de andere kant.

Hoewel de wet duidelijk is, blijkt men in de praktijk niet altijd te weten dat bepaalde subsidies voor bos en natuur niet onder de vrijstelling vallen. Volgens enkele respondenten levert dit problemen op in de belastingpraktijk (onterechte claims, veel correcties).

\section{Bijzonderheden in de praktijk}

De goedkeuring van de Europese Commissie voor de vrijstelling van de subsidieregelingen - indertijd verleend voor subsidies onder Programma Beheer - liep tot 1 januari 2014. Op 4 april 2016 heeft de Europese Commissie (EC) aangegeven geen bezwaar te hebben tegen de (verlenging van de) staatssteunmelding van de Subsidieregeling Kwaliteitsimpuls Natuur en Landschap (SKNL). De goedkeuring geldt voor de periode van 4 april 2016 tot en met 31 oktober 2017. Intussen is de verleende staatssteun in de voorafgaande periode (vanaf 1 januari 2014) ook goedgekeurd. De aanvraag voor verlenging van de goedkeuring van SKNL na 31 oktober 2017 wordt voorbereid door het Interprovinciaal Overleg (IPO). 


\section{$4 \quad$ Vrijstelling bos- en natuurterreinen bij voordeel uit sparen en beleggen}

\subsection{Beleidstheorie}

Inhoud

De vrijstelling bos- en natuurterreinen in box 3 is opgenomen in de Wet IB 2001, Art. 5.7 lid 1. De volgende bezittingen zijn van de heffingsgrondslag uitgezonderd: bossen, bepaalde natuurterreinen en de volgens de Natuurschoonwet 1928 (NSW) als zodanig aangewezen landgoederen (gebouwde eigendommen vallen niet onder de vrijstelling).

De natuurterreinen die onder de vrijstelling vallen zijn als volgt beschreven (Uitvoeringsbesluit IB 2001, art. 17):

heidevelden, hoogveenterreinen, zandverstuivingen, duinterreinen, kwelders, schorren, gorzen, slikken, riet- en ruigtelanden, laagveenmoerassen, voor zover deze terreinen geen landbouwgronden zijn.

De vrijstelling is alleen van toepassing als de belastingplichtige volledig eigenaar is van de grond. De vrijstelling geldt ook voor (de volle eigendom van) buitenlandse bos- en natuurterreinen.

\section{Beoogde doelgroep}

De vrijstelling is gericht op de niet-ondernemingsgewijze bosbouw en natuurbeheer. De beoogde doelgroep bestaat uit bos- en natuurterreineigenaren in de hoedanigheid van natuurlijk persoon (belastingplichtig voor de inkomstenbelasting) die geen onderneming drijft.

De belastingplichtige dient de volledige eigendom te hebben. De vrijstelling is niet van toepassing op gronden waarop een beperkt recht (zoals erfpacht, vruchtgebruik, opstal) is gevestigd. De bloot eigenaar van bos of natuurterrein waarop een beperkt recht is gevestigd dient de waarde in het economische verkeer van het bloot eigendom van de gronden tot het box 3-vermogen te rekenen; de beperkt gerechtigde dient de waarde van het beperkte recht in box 3 op te geven.

De doelgroep is groter dan de niet-ondernemingsgewijze bosbouw. Het gaat om alle eigenaren van bossen, natuurterreinen en landgoederen (waar ook andere terreintypen dan bos of natuurterrein onder kunnen vallen) voor zover deze voor de inkomstenbelasting niet kwalificeren als ondernemingsvermogen of een vermogensbestanddeel waarop het resultaat uit een werkzaamheid van toepassing is.

\section{Beoogde effecten}

De vrijstelling heeft als doel de instandhouding en ontwikkeling van bos en natuur (figuur 4.1). Bosen natuurterreinen vormen een publiek belang. Aangenomen wordt dat dit belang onvoldoende door de vrije markt wordt geborgd. De vrijstelling houdt in dat het particuliere vermogen in bos- en natuurterreinen van natuurlijke personen niet wordt belast, zodat het houden van particulier vermogen in de vorm van bos en natuur aantrekkelijker wordt. De vrijstelling voorkomt dat het betreffende vermogen in bos- en natuurterreinen moet worden gewaardeerd. 


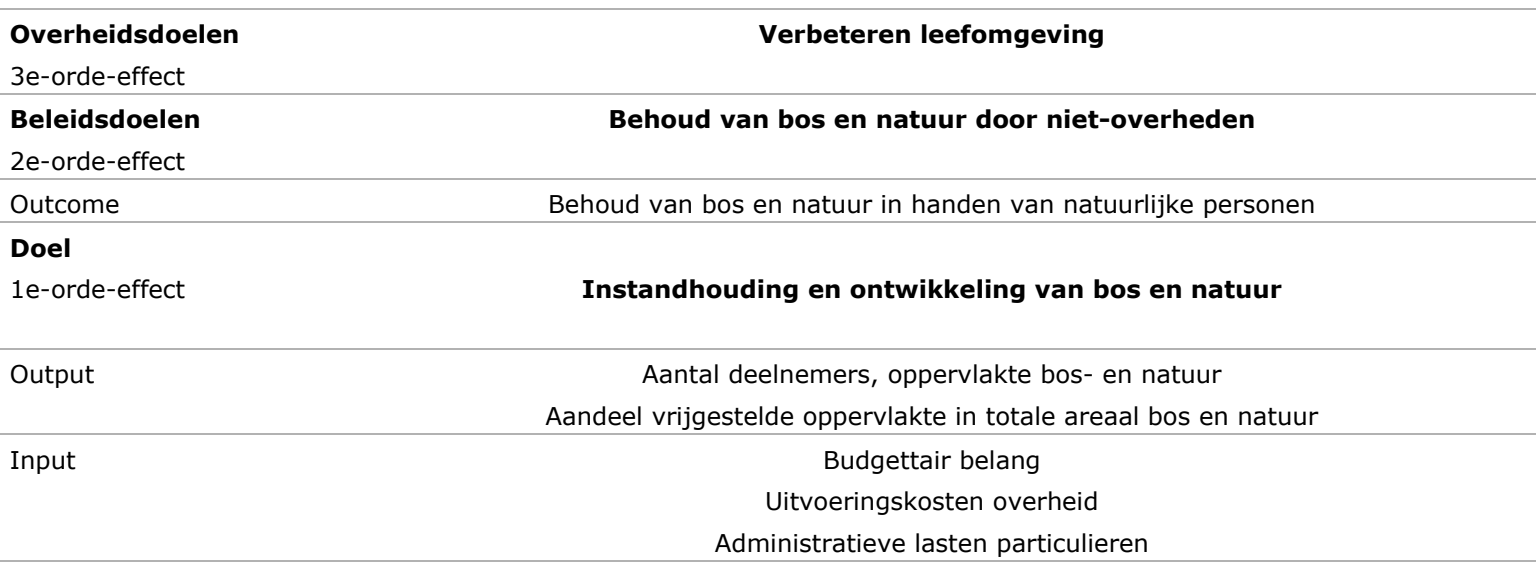

Figuur 4.1 Doelenboom van de vrijstelling bos- en natuurterreinen bij voordeel uit sparen en beleggen

\subsection{Doeltreffendheid}

\section{Doelgroep}

De vrijstelling is goed bekend bij de doelgroep. Voor zover ze niet kwalificeren als ondernemer, maken alle eigenaren met bos, natuurterreinen en NSW-landgoederen in volle eigendom gebruik van de vrijstelling. Dit wordt bevestigd door de respondenten van dit onderzoek. De vrijstelling draagt bij aan de aantrekkelijkheid van het particuliere bezit van bos en natuur.

De vrijstelling is beperkt tot de bezittingen in volle eigendom. Bloot eigenaren en vruchtgebruikers van NSW-landgoederen kunnen wel de fiscale faciliteiten van de NSW genieten, maar niet gebruik maken van de vrijstelling bij voordeel uit sparen en beleggen. Door enkele respondenten zijn hier vraagtekens bij geplaatst. Voor de huurder, pachter of erfpachter zal het in huur, pacht of erfpacht verkregen object meestal niet kwalificeren als een vermogensbestanddeel waarop box 3 van toepassing is, zodat deze groep geen belang heeft bij - een uitbreiding van - de vrijstelling.

\section{Overheidsbeleid}

De peiling onder de respondenten (bijlage 1) ondersteunt de veronderstelling dat de vrijstelling een positieve bijdrage levert aan de instandhouding en ontwikkeling van bossen en natuurterreinen in handen van natuurlijke personen. Het is niet mogelijk om deze bijdrage te kwantificeren.

\subsection{Doelmatigheid}

\section{Budgettair belang}

Het gebruik van de vrijstelling wordt niet centraal geregistreerd. De Miljoenennota schat het belang in de laatste jaren op 6 miljoen euro (tabel 4.1). Dit bedrag is gebaseerd op een oude studie van het LEI (Boers et al., 2005).

Tabel 4.1 Budgettair belang (miljoen euro) vrijstelling bos- en naturterreinen bij voordeel uit sparen en beleggen, 2010-2015

\begin{tabular}{rrrrrrr} 
& 2010 & 2011 & 2012 & 2013 & 2014 & 2015 \\
Budgettair belang & 6 & 6 & 6 & 6 & 6 & 6 \\
\hline
\end{tabular}

Bronnen: Miljoenennota 2012-2016. 
Alternatief

Een alternatief voor deze vrijstelling is een hogere tegemoetkoming door de overheden in de vorm van subsidies. Dit gaat naar verwachting gepaard met hogere uitvoeringskosten dan die voor de huidige vrijstelling.

Samenhang met andere regelingen

De Boswet heeft geen directe invloed op deze vrijstelling. De vrijstelling voor subsidies (zie hoofdstuk 3 ) is mede tot stand gekomen omdat de doelgroep voor die subsidieregelingen in box 1 of 3 valt.

Administratieve lasten doelgroep

Dankzij de vrijstelling zijn de administratieve lasten voor de doelgroep nihil. Zonder de vrijstelling dient het particuliere vermogen in bos- en natuurterreinen jaarlijks gewaardeerd te worden en dient deze in de aangifte te worden opgenomen. De jaarlijkse waardering kan mogelijk ondervangen worden door een forfaitaire waardering van de gronden.

Uitvoeringskosten overheid

De Vrijstelling bos- en natuurterreinen bij voordeel uit sparen en beleggen wordt niet aangegeven in het aangiftebiljet. De uitvoeringskosten van de overheid zullen nagenoeg nihil zijn; de registratie van de NSW-landgoederen zijn niet aan deze faciliteit toe te rekenen. 


\section{$5 \quad$ Vrijstelling overdrachtsbelasting natuurgrond}

\section{$5.1 \quad$ Beleidstheorie}

Inhoud

Overdrachtsbelasting wordt geheven over de verkrijging van in Nederland gelegen onroerende zaken en van rechten waaraan onroerende zaken zijn onderworpen. Het tarief van de overdrachtsbelasting bedraagt $2 \%$ voor woningen (sinds 15 juni 2011) en $6 \%$ voor overige onroerende zaken (Wet Belastingen op Rechtsverkeer (BRV), art. 14). De vrijstelling overdrachtsbelasting natuurgrond is vastgelegd in de Wet BRV, art. 15, eerste lid, onderdeel s. De inrichting en het beheer van de grond is geheel of nagenoeg geheel duurzaam afgestemd op het behoud en de ontwikkeling van natuur en landschap (zie het kader voor de definitie van natuurgrond).

Definitie natuurgrond

Onder natuurgrond als bedoeld in artikel 15, eerste lid, onderdeel s, van de wet, wordt verstaan grond bezet met houtopstanden en natuurterreinen als bedoeld in artikel 1, eerste lid, onderdelen b en $d$, en tweede lid, van het Rangschikkingsbesluit Natuurschoonwet 1928:

grond bezet met houtopstanden niet zijnde kweekgoed, kerstboomteelten, laagstamboomgaarden of snijgrienden;

natuurterreinen: heidevelden, hoogvenen, laagveenmoerassen, zandverstuivingen, duinterreinen, kwelders, slufters, schorren, gorzen, slikken, groene stranden, rietlanden, ruigten, struwelen, moerassen, vennen, poelen, beken, kleine rivieren, wielen, afgesloten rivierlopen, kreken, bronnen en sprengen, voor zover deze gronden niet in gebruik zijn als landbouwgrond;

kalkgraslanden, bloemrijke graslanden van het heuvelland, van het zand- en het veengebied of van het rivieren- en zeekleigebied, natte schraalgraslanden, dotterbloemgraslanden van beekdalen of van veenen kleigebieden, natte matig voedselrijke graslanden, droge schraalgraslanden van de hogere gronden, droge kalkarme duingraslanden, droge kalkrijke duingraslanden en binnendijkse zilte graslanden, voor zover deze gronden slechts in gebruik zijn voor begrazing of als hooiland en begroeid zijn met voor deze graslanden kenmerkende vegetatietypen.

De vrijstelling overdrachtsbelasting geldt ook voor de rechten van erfpacht of beklemming daarop. De vrijstelling is beperkt tot grond. Voor zover er opstallen aanwezig zijn, is de onderhavige vrijstelling niet van toepassing. ${ }^{8}$

De regeling is per 1 januari 2008 in werking getreden. Als voorwaarde voor de vrijstelling geldt dat tot minimaal 10 jaar na de verkrijging de natuurgrond nog steeds behouden en ontwikkeld wordt. Echter, als de natuurgrond wordt omgezet in bedrijfsmatig geëxploiteerde cultuurgrond (natuurgrond wordt weer landbouwgrond) is de belasting niet alsnog verschuldigd, mits gedurende het restant van de tienjaarstermijn de grond als bedrijfsmatig cultuurgrond wordt geëxploiteerd. Wordt binnen de tienjaarstermijn aan een opvolgende verkrijger overgedragen, dan blijft de oorspronkelijk verleende vrijstelling in stand, mits de opvolgende verkrijger het verkregene als natuurgrond blijft gebruiken of gaat gebruiken als bedrijfsmatig geëxploiteerd cultuurgrond.

Voor de in cultuurgrond omgezette natuurgrond gaat een nieuwe tienjaarstermijn lopen op grond van artikel 15, eerste lid, onderdeel q, Wet BRV, wanneer deze vervolgens wordt overgedragen. De

8 Onder artikel 9a NSW kan de overdracht van opstallen wel vrijgesteld zijn. 
omzetting van natuurgrond in cultuurgrond is op zich geen verkrijging voor de overdrachtsbelasting, zodat voor de omzetting geen nieuwe termijn gaat lopen.

De onderhavige vrijstelling is niet de enige vrijstelling van overdrachtsbelasting bij de verkrijging van natuurgrond. Al veel langer bestaat een vrijstelling onder de Natuurschoonwet 1928; hierbij geldt onder meer een instandhoudingsverplichting van 25 jaar en dient de natuurgrond onderdeel te zijn van een landgoed als gedefinieerd in de Natuurschoonwet 1928. Verder zijn veel verkrijgers van natuurgronden vrijgesteld van overdrachtsbelasting (bijvoorbeeld overheden, Staatsbosbeheer).

\section{Beoogde doelgroep}

De beoogde doelgroep van de vrijstelling zijn particulieren en particuliere organisaties die natuurgrond verkrijgen. De vrijstelling is onder voorwaarden ook van toepassing op de verkrijging van landbouwgrond, welke wordt ingericht of anderszins genoegzaam geschikt wordt gemaakt voor ontwikkeling tot natuurterrein.

\section{Beoogde effecten}

De vrijstelling overdrachtsbelasting natuurgrond beoogt een bijdrage te leveren aan de instandhouding van het private areaal natuur (figuur 5.1). Bescherming van natuurwaarden is een publiek belang dat door de overheid wordt geborgd. De overheid beoogt de instandhouding van natuur en de aankoop van natuur door private partijen (particulieren en overige organisaties) onder andere door deze fiscale faciliteit te ondersteunen.

$\mathrm{Er}$ is in de parlementaire stukken nauwelijks iets gezegd over het concrete doel van de vrijstelling. Wel kan uit de parlementaire geschiedenis worden afgeleid dat de overheid het van belang acht dat er zo min mogelijk drempels bestaan voor private organisaties en particulieren om natuurgrond aan te kopen en te onderhouden. Als de overheid natuurgrond aankoopt is dat al vrijgesteld door een algehele vrijstelling voor verkrijgingen door de overheid.



Figuur 5.1 Doelenboom van de vrijstelling overdrachtsbelasting natuurgrond

\subsection{Doeltreffendheid}

\section{Doelgroep}

De perceptie van de geraadpleegde personen is dat de doelgroep weliswaar niet volledig maar in een redelijke/voldoende mate wordt bereikt. Volgens respondenten is niet iedere notaris bekend met deze - vrij nieuwe - vrijstelling en doelgroep: particulieren en private organisaties die natuurgrond verkrijgen. 
De vrijstelling draagt in beperkte mate bij aan het behoud en de toename van natuur door nietoverheden. De vrijstelling is vooral belangrijk om natuurgrond nog enigszins 'liquide' te maken. Dat maakt het natuurbezit een aantrekkelijker investeringsobject voor particulieren dan zonder de vrijstelling.

\subsection{Doelmatigheid}

\section{Budgettair belang}

Volgens de Miljoenennota's is het budgettair effect van de vrijstelling de laatste jaren gemiddeld 3 miljoen euro (tabel 5.1).

Tabel 5.1 Budgettair belang (miljoen euro) vrijstelling overdrachtsbelasting natuurgrond, 2010-2015

\begin{tabular}{rrrrrrr} 
& 2010 & 2011 & 2012 & 2013 & 2014 & 2015 \\
Budgettair belang & 3 & 4 & 3 & 2 & 3 & 3 \\
\hline
\end{tabular}

Bronnen: Miljoenennota 2012-2016.

Voor de onderbouwing is de Belastingdienst gevraagd om informatie over het aantal en de waarde van de transacties. Volgens de ontvangen gegevens gaat het jaarlijks om 500 tot 750 transacties met een gemiddelde waarde van 74.000 euro per transactie in de periode 2010-2013 (tabel 5.2).

Tabel 5.2 Aantal en waarde (miljoen euro) van verkrijgingen van natuurgrond, 2010-2013

\begin{tabular}{lrrrr} 
& 2010 & 2011 & 2012 & 2013 \\
Aantal verkrijgingen & 523 & 576 & 661 & 741 \\
\hline Waarde van verkrijgingen & 58,1 & 44,1 & 50,8 & 32,7 \\
\hline
\end{tabular}

Bron: Belastingdienst.

Bij het beoordelen van het budgettaire belang moet rekening worden gehouden met het feit dat mocht de vrijstelling niet bestaan of komen te vervallen - voor een deel van de objecten een beroep gedaan kan worden op de vrijstellingen voor cultuurgrond (waar het bedrijfsmatig geëxploiteerde bossen betreft), de NSW-vrijstelling of voor verkrijgingen door Staatsbosbeheer, BBL, rijk, provincie, gemeente of waterschappen. De genoemde bossen zullen echter een klein gedeelte uitmaken van de gevallen waarin een beroep op die vrijstellingen wordt gedaan. Voor de NSW-vrijstelling gelden vrij stringente voorwaarden en de verkrijgingen door overheden, SBB en BBL zitten niet in de cijfers van de vrijstelling voor natuurgrond.

\section{Alternatieven}

Een alternatief voor de vrijstelling is een subsidie voor de verschuldigde overdrachtsbelasting, zoals deze heeft gegolden voor Terreinbeherende Organisaties (Mededeling van 26 augustus 1991, nr. VB91/543). Dit alternatief is niet doelmatig omdat de uitvoeringskosten hoger zullen zijn (dubbele actie: eerst invorderen, vervolgens uitkeren). Een ander alternatief is een ongeclausuleerde vrijstelling voor natuurgrond. Betwijfeld kan worden of dit alternatief in het belang is van de natuur. De verkrijger van de grond hoeft er dan zelfs niet voor te zorgen dat het gedurende 10 jaar natuurgrond blijft.

\section{Samenhang met andere regelingen}

De vrijstelling overdrachtsbelasting natuurgrond overlapt met de vrijstelling sub $\mathrm{m}$ en $\mathrm{u}$, maar deze laatste vrijstellingen hebben specifieke verkrijgers (BBL en SBB) op het oog. De definitie van natuurgrond komt overeen met de vrijstelling overdrachtsbelasting onder de NSW. De volgtermijn van 
de algemene vrijstelling overdrachtsbelasting natuurgrond is echter veel korter dan die van de NSWvrijstelling.

Administratieve lasten doelgroep

De administratieve lasten voor de doelgroep zijn te verwaarlozen. De grondslag voor de - vrijgestelde - belasting wordt over het algemeen bepaald door de koopsom. Het beroep op de vrijstelling zal in de notariële akte gedaan worden, wat geen extra werk oplevert voor de belastingplichtige.

\section{Uitvoeringskosten overheid}

De uitvoeringskosten bij de overheid zijn gering. De notaris doet de aangifte overdrachtsbelasting, gelijktijdig met de aanbieding ter registratie van de akte van levering, en zal de status van de grond beoordelen. De controle door de Belastingdienst van het beroep op de vrijstelling valt binnen de reguliere aangiftebehandeling. Verder zal de Belastingdienst de tienjaarstermijn controleren.

Bijzonderheden in de praktijk

Voor particulieren vertoont de vrijstelling grote samenhang met de cultuurgrondvrijstelling en de NSW-vrijstelling van artikel 9a Natuurschoonwet 1928. Vanwege de kortere termijn van de instandhoudingsvoorwaarde prefereert de praktijk de onderhavige natuurgrondvrijstelling; subsidiair kan nog een beroep op de NSW-vrijstelling worden gedaan. 


\section{$6 \quad$ Vrijstelling overdrachtsbelasting Wet Inrichting Landelijk Gebied (WILG)}

\subsection{Beleidstheorie}

Inhoud

De vrijstelling overdrachtsbelasting in het kader van de Wet Inrichting Landelijk Gebied (WILG) is vastgelegd in de Wet op belastingen van rechtsverkeer (Wet BRV), art 15, eerste lid, onderdeel I. De vrijstelling gold ook al voor verkrijgingen krachtens de Ruilverkavelingswet 1954 en de Landinrichtingswet 1985.

Vrijgesteld zijn verkrijgingen van landerijen krachtens herverkaveling en kavelruil. Herverkaveling wordt door de overheid opgelegd, terwijl de kavelruil vrijwillig is.

Als de verwerving in het kader van de herverkaveling plaatsvindt voordat de akte van toedeling van landerijen is afgerond, moet voor de vrijstelling overdrachtsbelasting schriftelijke instemming van de ruilverkavelingscommissie zijn verkregen.

Als een kavelruilovereenkomst (ruilverkaveling bij overeenkomst, vastgelegd in openbare registers) aan de voorwaarden van de WILG (art. 85) voldoet, zijn de verkrijgingen krachtens de kavelruilovereenkomst vrij van overdrachtsbelasting. ${ }^{9}$

Bij Besluit inrichting landelijk gebied (BILG) art 31 a (sinds 1/1/2010) zijn 'verboden categorieën' zoals grond in bebouwde kom, woonwijk, bedrijventerrein, recreatiepark en ontgronding uitgesloten van de vrijstelling.

\section{Beoogde doelgroep}

De beoogde doelgroep van de vrijstelling overdrachtsbelasting WILG wordt gevormd door verkrijgers van grond in het kader van herverkaveling en kavelruil. Hierbij gaat het vooral - maar niet uitsluitend - om landbouwgrond.

\section{Beoogde effecten}

De WILG is er op gericht een collectieve structuurverbetering van het landelijk gebied te realiseren (figuur 6.1). De wet zegt het zo:

'Landinrichting strekt tot verbetering van de inrichting van het landelijke gebied overeenkomstig de functies van dat gebied, zoals deze in het kader van de ruimtelijke ordening zijn aangegeven.' ${ }^{10}$

Hierbij gaat het om zowel landbouwzaken (zoals de bedrijfsomvang, verkavelingssituatie, waterbeheersing, ontsluiting van agrarische bedrijven en dergelijke) als om natuur en landschap, infrastructuur, recreatie en cultuurhistorie.

De vrijstelling moet bevorderen dat gronden in andere handen kunnen overgaan, zodat de wegen, waterlopen en overige infrastructuur kunnen worden aangelegd en gronden voor eigenaren dichter bij elkaar komen te liggen. De vrijstelling bevordert de aanpassing door de aankoop en ruil van gronden te faciliteren.

\footnotetext{
${ }^{9}$ Voor uitgebreide informatie en uitleg ten aanzien van kavelruil: Rheinfeld (2014).

${ }^{10}$ Art. 16 Wet inrichting landelijk gebied.
} 


\begin{tabular}{|c|c|}
\hline $\begin{array}{l}\text { Overheidsdoelen } \\
\text { 3e-orde-effect }\end{array}$ & Structuurversterking van de economie \\
\hline $\begin{array}{l}\text { Beleidsdoelen } \\
\text { 2e-orde-effect }\end{array}$ & Versterking van de fysieke en natuurlijke leefomgeving \\
\hline Outcome & $\begin{array}{l}\text { De nagestreefde inrichting van het landelijke } \\
\text { gebied wordt tegen lagere kosten bereikt }\end{array}$ \\
\hline Output & Aantal en omvang transacties onder de vrijstelling \\
\hline Input & $\begin{array}{c}\text { Budgettair belang } \\
\text { Uitvoeringskosten overheid } \\
\text { Administratieve lasten bedrijven }\end{array}$ \\
\hline
\end{tabular}

Figuur 6.1 Doelenboom van de vrijstelling overdrachtsbelasting Wet Inrichting Landelijk Gebied

\subsection{Doeltreffendheid}

\section{Doelgroep}

Verkrijgers krachtens landinrichting is een brede groep. De vrijstelling sluit aan bij de behoefte van de beoogde doelgroep om de structuur van het landelijk gebied te verbeteren. Van de vrijstelling wordt volgens de respondenten veel gebruik gemaakt. Naar verluidt kunnen ook partijen buiten de beoogde doelgroep van de vrijstelling gebruik maken, waarbij niet zozeer de structuurverbetering de boventoon voert, maar het fiscale voordeel (met name ten aanzien van de gebouwen).

\section{Overheidsbeleid}

Vooral bij herverkaveling is actieve sturing op structuurverbetering mogelijk. Ook bij planmatige kavelruil is dit (zij het in iets mindere mate gezien het vrijwillige karakter) het geval. Het doel van structuurverbetering is daarbij duidelijk in het vizier. Bij 'losse' kavelruil is dit, vooral gezien het feit dat art. 16 WILG (objectieve verbeteringseis) niet relevant is voor kavelruilen, minder het geval. Het is mogelijk dat een kavelruil om fiscale redenen wordt geïnitieerd, waarbij de eventuele structuurverbetering een bijkomstigheid is.

\subsection{Doelmatigheid}

Budgettair belang

Gezien het ruime toepassingsbereik van de WILG-vrijstelling, zou het budgettaire belang vrij groot kunnen zijn. Volgens de Miljoenennota's is het budgettaire belang beperkt tot 1 miljoen euro per jaar (tabel 6.1).

Tabel 6.1 Budgettair belang (miljoen euro) vrijstelling overdrachtsbelasting WILG, 2010-2015

\begin{tabular}{rrrrrrr} 
& 2010 & 2011 & 2012 & 2013 & 2014 & 2015 \\
Budgettair belang & 1 & 1 & 1 & 1 & 1 & 1 \\
\hline
\end{tabular}

Bronnen: Miljoenennota 2012-2016.

De cijfers over de waarde van geregistreerde verkrijgingen onder de WILG lijken die schatting te bevestigen (tabel 6.2). 


\begin{tabular}{lrrrr} 
& 2010 & 2011 & 2012 & 2013 \\
Aantal verkrijgingen & 151 & 215 & 169 & 160 \\
\hline Waarde verkrijgingen & 17,4 & 17,3 & 8,0 & 15,6 \\
\hline
\end{tabular}

Bron: Belastingdienst.

Er zijn redenen om aan te nemen dat de registratie van verkrijgingen geen volledige weergave is van de in de praktijk geruilde waarden. Bij kavelruil hoeven de waarden van de geruilde onroerende zaken niet in de akte te staan. Als bijvoorbeeld vier personen grond ruilen, dan kan het voldoende zijn dat er in de akte alleen is opgenomen wat bepaalde personen bij moeten betalen. Het volgende voorbeeld maakt dit duidelijk.

Stel dat vier personen onroerende zaken inbrengen ter waarde van 1.000.000 euro en door de kavelruil andere gronden terug krijgen. De waarde daarvan kan afwijken van de waarde van wat zij hebben ingebracht. In de akte hoeft alleen maar te staan wat een of meer van de vier personen moeten bijbetalen. Als $A$, $B$ en $C$ meer grond krijgen dan zij hebben ingebracht en $D$ minder, dan moeten A, B en C bij voorbeeld respectievelijk 10.000, 5.000 en 15.000 euro aan D betalen. Dat zijn dan mogelijk de enige bedragen die in de akte staan. De registrator zal - als de bedragen al ingebracht worden - 30.000 invoeren, terwijl er voor 1.000 .000 is vrijgesteld. Het ingebrachte belastbare bedrag is dan maar een fractie van het werkelijke belang.

Tegen deze achtergrond kunnen de cijfers van tabel 6.2 voor de vrijstelling van verkrijgingen onder de WILG een duidelijke onderschatting zijn van de praktijk.

\section{Samenhang met andere regelingen}

Verkrijging op grond van landinrichting zal zeer vaak ook verkrijging van cultuur- of natuurgrond inhouden. Hiervoor zou een beroep kunnen worden gedaan op algemene vrijstellingen overdrachtsbelasting voor cultuurgrond en natuurgrond. Indien mogelijk geeft de praktijk de voorkeur aan een beroep op de vrijstelling van onderdeel I boven die van de onderdelen q en s, omdat de vrijstelling van onderdeel I geen nadere voorwaarden kent (hooguit subsidiair bij kavelruil indien de kavelruil niet voldoet aan de eisen van 85-88 WILG en 31a BILG). Daarnaast zien de vrijstelling cultuurgrond en natuurgrond alleen op grond en kan de vrijstelling voor landinrichting ook betrekking hebben op opstallen.

\section{Administratieve lasten doelgroep}

De administratieve lasten voor de doelgroep zijn gering. Het beroep op de vrijstelling wordt gedaan in de notariële akte.

\section{Uitvoeringskosten overheid}

De uitvoeringskosten van de vrijstelling zijn gering. De notaris doet de aangifte overdrachtsbelasting, gelijktijdig met de aanbieding ter registratie van de akte van levering. De controle door de Belastingdienst van het beroep op de toepassing van de vrijstelling valt binnen de reguliere aangiftebehandeling. Exacte cijfers over de uitvoeringskosten zijn niet beschikbaar.

\section{Bereik van de vrijstelling}

Respondenten achten het mogelijk dat bedrijfsverplaatsingen en -overdrachten met kavelruil worden gerealiseerd zonder dat dit leidt tot een objectieve verbetering van de inrichting van het landelijk gebied. Gelet op het in artikel 16 WILG genoemde algemene doel van de landinrichting kan dan ook de vraag worden gesteld of de vrijstelling een te ruim bereik heeft.

De vormgeving van artikel 15, lid 1 sub I is ongeclausuleerd: voor de herverkaveling is dit te begrijpen (een herverkaveling 'overkomt je'), voor de kavelruil minder (deze is immers actief te 'sturen'). Een nadere clausulering door invoering van een volgtermijn of een nieuwe, aan de huidige multisectorale toepassingsmogelijkheden van de kavelruil aangepaste objectieve verbeteringseis, dient overwogen te worden. Volgens Rheinfeld is hier wel een nuance op zijn plaats: 
'het succes van de kavelruil wordt thans voor het overgrote deel bepaald door de eenvoudige fiscale behandeling en facilitering. Aanscherping van de fiscale vrijstelling dient dus zorgvuldig en met oog voor de voordelen van een veelvuldige, eenvoudige en snelle toepassing en werking van het kavelruilinstrument te gebeuren.'

\section{Wetstekst}

De tekst van de fiscale vrijstelling van artikel 15, lid 1, onderdeel I, Wet BRV kan geactualiseerd worden: verwijzingen naar wettelijke regelingen die in de praktijk niet meer worden toegepast omdat zij uitgewerkt zijn of vervangen zijn door een andere regeling (Ruilverkavelingswet 1954, Reconstructiewet Midden-Delfland, Herinrichtingswet Oost-Groningen en de Gronings-Drentse Veenkoloniën) kunnen worden geschrapt. 


\section{$7 \quad$ Vrijstelling verkrijging door Bureau Beheer Landbouwgronden (BBL)}

\subsection{Beleidstheorie}

Inhoud

In de Wet op belastingen van rechtsverkeer (Wet BRV), art 15, eerste lid, onderdeel m, is voor verkrijgingen door het bureau beheer landbouwgronden (BBL) een vrijstelling van overdrachtsbelasting opgenomen. De vrijstelling is een formalisering van de reeds voor de invoering van de Wet BRV bestaande situatie. De vrijstelling heeft alleen betrekking op verkrijgingen door BBL (subjectieve vrijstelling). Het is een generieke vrijstelling, waar geen voorwaarden aan zijn gesteld. De vrijstelling is onder meer nodig om transacties tussen overheden onderling niet te belasten (voorkomen van vestzak-broekzakbetalingen). Provincies hebben ook een vrijstelling bij verkrijgingen.

\section{Beoogde doelgroep}

De beoogde doelgroep van de vrijstelling, BBL, ontleent zijn bestaansrecht aan de Wet Agrarisch Grondverkeer (WAG). Deze wet verleent het BBL onder meer een voorkeursrecht bij de verwerving van landbouwgronden en natuurterreinen. BBL heeft als taak om gronden te verwerven, gronden tijdelijk te beheren en onroerende zaken te vervreemden. In 2009 verwierf BBL meer dan 10.000 ha en vervreemdde meer dan 8.000 ha. Mede als gevolg van de decentralisatie van het natuurbeleid zijn de activiteiten van BBL de afgelopen jaren sterk gedaald. In 2014 en 2015 is nauwelijks meer grond verworven en mondjesmaat vervreemd. Naar verwachting wordt BBL voor 2020 daadwerkelijk beëindigd. Tot die tijd is BBL voornamelijk bezig met het afwikkelen van lopende opdrachten. Dat betreft voornamelijk het verkopen van gronden.

\section{Beoogde effecten}

De vrijstelling beoogt het tijdelijk beheer van landerijen door BBL te faciliteren (figuur 7.1). Dit beheer vindt plaats in het kader van overheidsbeleid. Dit beleid is erop gericht om een collectieve structuurverbetering van het landelijk gebied te realiseren. BBL opereert als een intermediair, die op deze wijze een bijdrage levert aan de verbetering van de structuur van het landelijk gebied. Het is een publiek belang dat dat werk zo onbelemmerd mogelijk kan worden uitgevoerd.

\begin{tabular}{|c|c|}
\hline $\begin{array}{l}\text { Overheidsdoelen } \\
\text { 3e-orde-effect }\end{array}$ & Structuurversterking van de economie \\
\hline $\begin{array}{l}\text { Beleidsdoelen } \\
\text { 2e-orde-effect }\end{array}$ & Verbetering leefomgeving \\
\hline Outcome & $\begin{array}{l}\text { Versnelde uitvoering overheidsbeleid voor de structuurverbetering } \\
\qquad \text { van het landelijk gebied }\end{array}$ \\
\hline $\begin{array}{l}\text { Doel } \\
\text { 1e-orde-effect }\end{array}$ & Versterken van de structuur van het landelijk gebied \\
\hline Output & Aantal en omvang transacties onder de vrijstelling \\
\hline Input & $\begin{array}{c}\text { Budgettair belang } \\
\text { Uitvoeringskosten overheid } \\
\text { Administratieve lasten bedrijven }\end{array}$ \\
\hline
\end{tabular}

Figuur 7.1 Doelenboom van de vrijstelling verkrijging door BBL 


\subsection{Doeltreffendheid}

\section{Doelgroep}

De vrijstelling is overzichtelijk en duidelijk en sluit geheel aan op de behoefte van BBL. Er is geen twijfel over dat de doelgroep van de vrijstelling volledig wordt bereikt.

\section{Overheidsbeleid}

Van oudsher heeft de vrijstelling bijgedragen aan het overheidsbeleid voor de structuurverbetering van het landelijk gebied (Albregtse et al., 2008). Doordat BBL wordt beëindigd, verkleint de grondpot $B B L$ en neemt het effect op structuurverbetering af. Voldoende ruilgronden zijn echter een basisvoorwaarde voor een geslaagd verkavelingsproces. In de toekomst zal de positie/rol van BBL moeten worden ingenomen door andere partijen/instanties.

\subsection{Doelmatigheid}

Budgettair belang

Volgens de Miljoenennota's heeft het budgettaire belang van de BBL-vrijstelling jarenlang boven 10 miljoen euro gelegen, maar dit neemt de laatste jaren snel af (tabel 7.1).

Tabel 7.1 Budgettair belang (miljoen euro) vrijstelling overdrachtsbelasting BBL, 2010-2015

\begin{tabular}{rrrrrrr} 
& 2010 & 2011 & 2012 & 2013 & 2014 & 2015 \\
Budgettair belang & 15 & 7 & 11 & 3 & 8 & 4 \\
\hline
\end{tabular}

Bronnen: Miljoenennota 2012-2016.

Aangezien BBL in principe slechts tijdelijk eigenaar is van de gronden die zij verwerft, gaat het hier feitelijk om een uitstel van de heffing van overdrachtsbelasting. De uiteindelijke eigenaar zal overdrachtsbelasting moeten betalen (of zelfstandig een beroep op een vrijstelling moeten doen).

Gegevens van de Belastingdienst over het beroep op de vrijstelling en de grondslag ervan, bevestigen dat de verkrijgingen van BBL sinds 2010 sterk zijn afgenomen. Zo bedroeg de waarde in 2013 nog geen $60 \mathrm{mln}$. euro, tegen meer dan $250 \mathrm{mln}$. euro in 2010 (tabel 7.2).

Tabel 7.2 Aantal en waarde (miljoen euro) van verkrijgingen door BBL, 2010-2013

\begin{tabular}{lrrrr} 
& 2010 & 2011 & 2012 & 2013 \\
Aantal verkrijgingen & 497 & 349 & 271 & 208 \\
\hline Waarde verkrijgingen & 252,3 & 116,7 & 94,6 & 56,9
\end{tabular}

Bron: Belastingdienst.

\section{Samenhang/overlap met andere regelingen}

Anders dan de algemene vrijstellingen overdrachtsbelasting voor cultuurgrond en natuurgrond is de BBL-vrijstelling een ongeclausuleerde vrijstelling. Er zijn geen volgtermijnen, exploitatie-eisen, eisen aan type onroerende zaken en dergelijke, maar alleen specifieke eisen aan de hoedanigheid van de verkrijgende partij.

Administratieve lasten doelgroep

De administratieve lasten voor de doelgroep zijn beperkt tot het beroep op de vrijstelling in de notariële akte. 


\section{Uitvoeringskosten overheid}

De uitvoeringskosten van de overheid zijn zeer gering. Er is weinig controle nodig.

\section{Bijzonderheden in de praktijk}

Na de voorgenomen opheffing van BBL blijft er behoefte aan gronden als smeerolie voor (onder meer) landinrichtingsprojecten. Introductie van vrijstellingen voor grondbanken en andere vergelijkbare instanties kan wenselijk zijn om de grondmobiliteit op een gewenst niveau te kunnen houden. 


\section{Literatuur en websites}

Albregtse, D.A., G.S. Venema, R. Van Ovost, H.B. van der Veen en P. Kavelaars, 2008. Evaluatie van vrijstellingen voor de landbouw in de overdrachtsbelasting. Den Haag, LEI Rapport 6.08.02

Bakker, A.J.J., D.A. Albregtse, R.B. Doorneweert, P. Kavelaars, G.S. Venema en M.N. van Wijk, 2005. Fiscale faciliteiten en knelpunten natuurontwikkeling door particulieren. Den Haag, LEI, Rapport 5.05.06

Boers, A. en M.J. Koning, 2005. Belastinguitgaven door fiscale faciliteiten voor natuurbeleid. Den Haag, LEI, Rapport 6.05.16 (http://library.wur.nl/WebQuery/wurpubs/fulltext/25772)

Compendium van de Leefomgeving > CBS. CBS/CLO/dec13/0060

CBS, PBL, Wageningen UR, 2014. Bestemming van verdwenen landbouwgrond; periode 2000- 2010 (indicator 1530, versie 02, 5 juni 2014).

Niessen, R.E.C.M., 2013. Conclusie van A-G Niessen van 6 maart 2013, nr. 12/02449.

Rheinfeld, J.W.A., 2013. Kavelruil anno 2013, een fiscale nabrander. Tijdschrift voor Agrarisch Recht, nr. 9.

Rheinfeld, J.W.A., 2014. Kavelruil; Civiel en fiscaal: waar lopen de grenzen? Publicaties vanwege het Centrum voor Notarieel Recht, Kluwer.

Schelhaas, M.J., A.P.P.M. Clerkx, W.P. Daamen, J.F. Oldenburger, G. Velema, P. Schnitger, H. Schoonderwoerd en H. Kramer, 2014. Zesde Nederlandse Bosinventarisatie; Methoden en basisresultaten. Alterra-rapport 2545 ISSN 1566-7197.

Schenk, S.F.J.J. en P.L.F. Seegers, 2013. De Bosbouwvrijstelling. Kluwer, fiscale brochure

Silvis, H.J. en M.J. Voskuilen, 2015. Bedrijfsuitkomsten in de Nederlandse particuliere bosbouw over 2013. Wageningen, LEI Wageningen UR (University \& Research centre), LEI Report 2015-067.

Subsidiestelsel Natuur- en Landschapsbeheer

Stevens, 2014., Wet IB 2001

Van Es, J.A.G., 'Bosbouwvrijstelling', NTFR Beschouwingen 2014/5

http://www.tweedekamer.nl/kamerstukken/brieven_regering/detail?id=2015Z25273\&did=2015D5124 5. 


\section{Bijlage 1 Geraadpleegde personen}

\begin{tabular}{ll} 
Categorie & Personen \\
& $\begin{array}{l}\text { Marnix Koopmans (VNO-NCW, voorheen ministerie van EZ) } \\
\text { Peter van der Knaap } \\
\text { Reinder van der Wal }\end{array}$ \\
\hline Ministerie van Financiën & $\begin{array}{l}\text { Corné Gosen (Inkomstenbelasting/Vennootschapsbelasting) } \\
\text { Kees Lambregtse (Overdrachtsbelasting) }\end{array}$ \\
\hline Belastingdienst & $\begin{array}{l}\text { Staf Willemen en Marco van der Voord (Overdrachtsbelasting) } \\
\text { Juan Hernandez (Inkomstenbelasting/Vennootschapsbelasting) }\end{array}$ \\
\hline Federatie Particulier Grondbezit & Pieter Seegers (Voorzitter platform landbouwnormen) \\
\hline Rentmeesters & Samuel Griessen \\
& Frederik Evelein \\
\hline Particuliere eigenaren & Gijs Sijpveld ('t Schoutenhuis) \\
& Wiet van Lanschot (Van Lanschot Nannenga Naus) \\
\hline Staatsbosbeheer & Dhr. E. ten Kate \\
\hline Kadaster & Mevr. A. Ritskes \\
\hline Accountancy & Ton Sterrenburg en Elles van Hierden \\
\hline Notariaat & Jan van Rheenen (voorheen DLG) \\
\hline Overige deskundigen & Aart Bakker (EY) \\
\hline
\end{tabular}




\section{Bijlage 2 Bos en natuur in Nederland: enkele kerncijfers}

\section{Bodemgebruik}

Het areaal bos en natuur (open natuurlijk terrein) beslaat een kleine $12 \%$ van het bodemgebruik in Nederland. Tussen 2000 en 2010 is het totale areaal bos en natuur in Nederland nauwelijks veranderd. Volgens het CBS is het areaal licht gestegen, als resultante van een kleine daling van het bosareaal en een iets grotere stijging van het areaal natuur (tabel B2.1). De oppervlakte verkeersterrein, bebouwd terrein en semi-bebouwd terrein (rode ruimte) is duidelijk toegenomen en de oppervlakte recreatie-, agrarisch, natuurlijk terrein en bos (groene ruimte) afgenomen. De afname van de groene ruimte bestond uit agrarisch terrein.

Tabel B2.1 Bodemgebruik $\left(\mathrm{km}^{2}\right)$ Nederland, 2000 en 2010

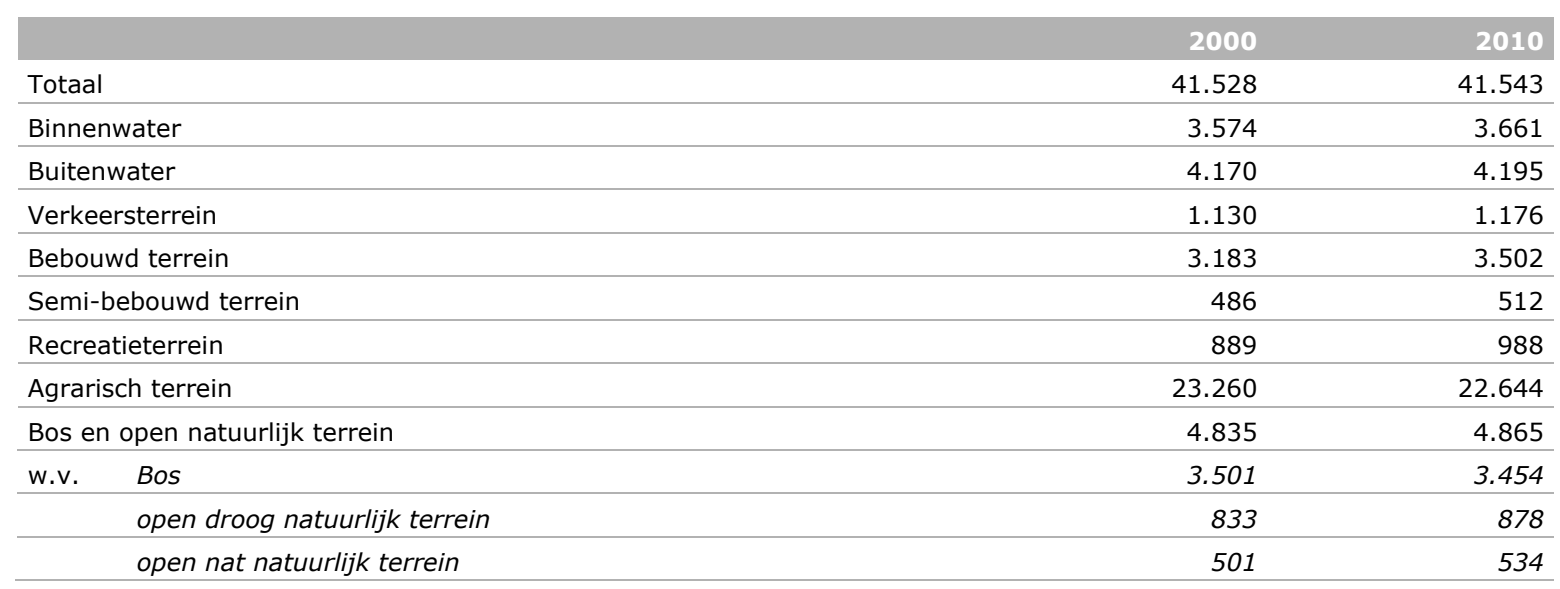

Bron: Compendium van de Leefomgeving > CBS. CBS/CLO/dec13/0060.

\section{Ontwikkeling bosareaal}

Volgens schattingen van de Zesde Nederlandse Bosinventarisatie (NBI6) ${ }^{11}$ is het bosareaal in Nederland licht toegenomen ten opzichte van vorige metingen, tot 373.480 ha. Ruim driekwart van het bos is opgaand bos, terwijl 3,5\% als een bijzondere bosvorm wordt getypeerd, zoals hakhout, middenbos of parkbos. Onder overige beplantingen valt 13,5\%, zoals houtwallen, singels, landschappelijke beplantingen en recreatiebos.

Iets meer dan de helft van het bos wordt gedomineerd door naaldbomen, maar dit aandeel neemt langzaam af. Grove den is nog steeds de belangrijkste boomsoort met ongeveer een derde van het totale areaal, maar dit neemt licht af. Bij de loofbomen is eik het belangrijkst (17,2\% van het areaal). Opvallend zijn de toename van berk (van 5,8 naar 6,6\%) en de afname van populier (van 4,9\% naar $3,3 \%)$. Het Nederlandse bos wordt nog steeds ouder. Naaldbos is nu gemiddeld 67 jaar oud, terwijl loofbos gemiddeld 58 jaar oud is.

Jaarlijks wordt naar schatting ongeveer 1,3 miljoen $\mathrm{m}^{3}$ hout geveld (MFV 3,6 $\mathrm{m}^{3}$ ha-1 jr-1 en NBI6 $3,4 \mathrm{~m}^{3}$ ha-1 jr-1). Daarvan wordt ruwweg twee derde geveld in naaldbossen en een derde in loofbossen. Belangrijke soorten zijn grove den (28\%), douglas, (12\%), eik (10\%), lariks (9\%), fijnspar ( $8 \%$ ) en populier (7\%). Over het algemeen hebben de loofboomsoorten een lager aandeel in de velling dan verwacht mag worden op grond van het aandeel in zowel oppervlakte als bijgroei, en bij naaldboomsoorten geldt het omgekeerde. Uitzondering hierop is de populier waar relatief veel geveld wordt. Op ruim de helft van de heropgenomen steekproefcirkels werd individuele kap vastgesteld, en

\footnotetext{
${ }^{11}$ Schelhaas et al. (2014)., Deze inventarisatie, uitgevoerd in 2012 en 2013, is de opvolger van het Meetnet Functievervulling (MFV), uitgevoerd in 2001-2005.
} 
op 4\% een kaalkap. Op 43\% van deze cirkels heeft sinds het MFV geen kap plaatsgevonden. Dit is vooral vaak het geval bij Natuurmonumenten (60\%), natuurbeschermingsorganisaties (49\%) en privébezit (49\%).

\section{Eigendom van bos}

De bosinventarisatie NBI6 heeft onder meer de eigendomssituatie van het bos opnieuw in kaart gebracht. De eigenaren zijn ingedeeld naar bezitsvorm (particulier, particulier georganiseerd, bedrijf, overheid, onbekend) en type bedrijf. De indeling naar type omvat onder andere type overheid (welk ministerie, provincies, gemeente, waterschappen), type bedrijf (landgoed, financieel, vastgoed, NUTS bedrijf, overig) en overige relevante indelingen (onder andere provinciale landschappen, natuurbeschermingsorganisaties, gemeenschappelijk bezit, vereniging, stichting, privépersoon). Op basis van de combinatie van bezitsvorm en type bedrijf is een indeling in eigenaarscategorieën gemaakt, analoog aan de indeling in het MFV (tabel B2.2). In grote lijnen is de indeling hetzelfde, alleen bij de MFV-categorieën overige publiekrechtelijke organisaties, natuurbeschermingsorganisaties en particulier was de toebedeling soms lastig omdat doelstellingen en bezitsvorm niet altijd duidelijk zijn.

Tabel B2.2 Eigendom van bos volgens MFV en NBI6

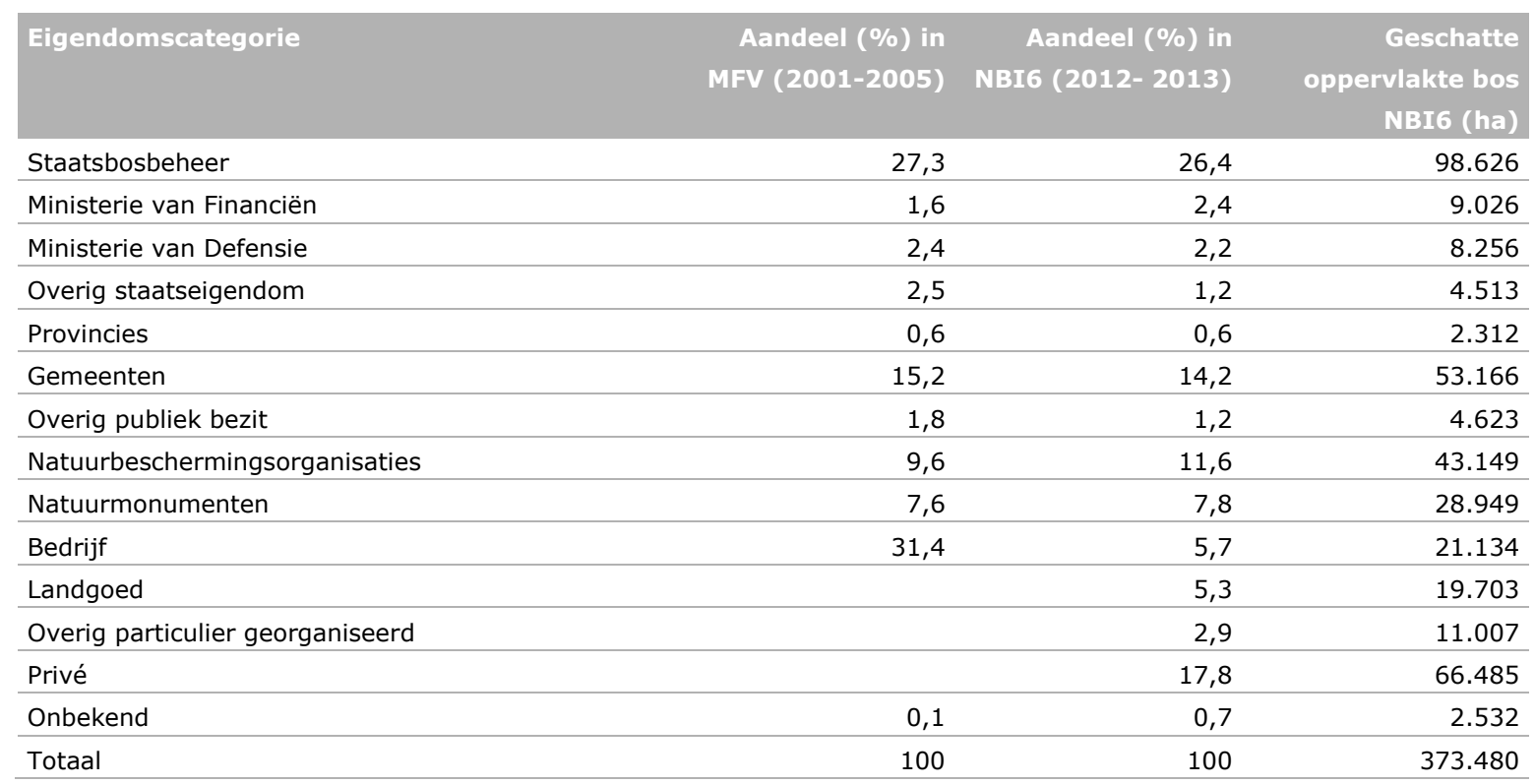

Bron: NBI6.

Verschillen tussen MFV en NBI6 zijn dus deels het gevolg van onzekerheden in de indeling. De MFVcategorie particulier is nu opgesplitst in landgoed, bedrijven, privépersonen en overig particulier georganiseerd. De categorie landgoed omvat alle eigendommen waarvan uit de naam of doelstelling (mits gevonden op het web) blijkt dat het als landgoed beheerd wordt. Dat kan inhouden dat niet alle landgoederen als zodanig onder de Natuurschoonwet erkend zijn, en dat een aantal landgoederen niet als zodanig herkend zijn uit de lijst met namen van eigenaren. Overig particulier omvat alle stichtingen en verenigingen. Onder Financiën valt het Kroondomein en het Rijksvastgoed- en ontwikkelingsbedrijf. Onder overig staatseigendom vallen Rijkswaterstaat, centraal orgaan asielzoekers en overige ministeries. Onder overig publiek bezit vallen de waterschappen, hoogheemraadschappen, recreatieschappen en bureau beheer landbouwgronden.

Onder natuurbeschermingsorganisaties vallen de Landschappen en de waterleidingduinen. Voor bijna alle eigenaarscategorieën zijn de oppervlakteschattingen van NBI6 hoger dan de registraties bij het Bosschap (Bosschap, 2012). Dit komt waarschijnlijk door verschillen in de gehanteerde bosdefinitie. Bij particulieren is het verschil veel groter doordat eigenaren met een bosoppervlak kleiner dan 5 ha zich niet verplicht hoefden te registreren. Ten opzichte van het MFV (Dirkse et al., 2007) is de eigendomssituatie van de Nederlandse bossen weinig veranderd. De verschillen zijn over het 
algemeen klein en worden deels veroorzaakt door onzekerheden in de toewijzing van eigenaren aan categorieën.

Figuur B2.1 geeft een overzicht van het bosareaal per provincie. De provincies met het grootste areaal bos zijn Gelderland en Noord-Brabant.

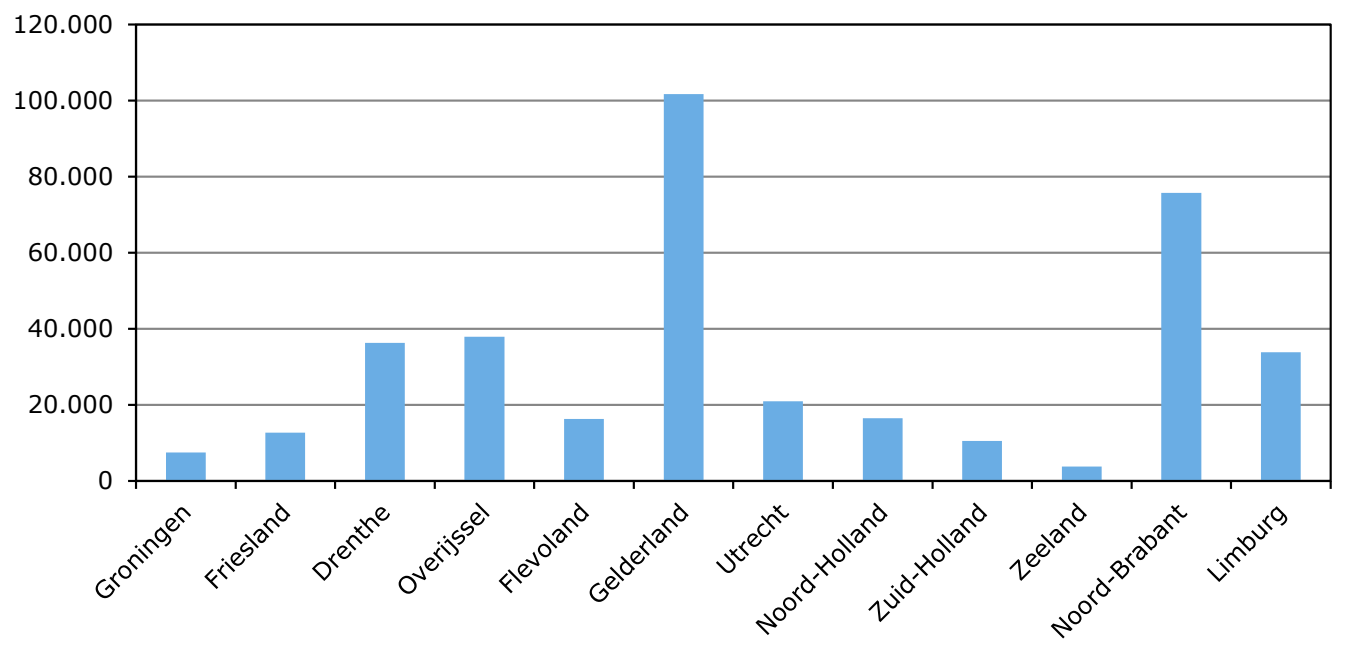

Figuur B2.1 Bosareaal (ha) per provincie Bron: NBI6.

\section{Bedrijfsuitkomsten particuliere bosbouw}

Over de bedrijfsuitkomsten van de particuliere bosbouw wordt jaarlijks door Wageningen Economic Research gerapporteerd in opdracht van het ministerie van Economische Zaken. ${ }^{12}$ Hierbij gaat het om de bedrijfsresultaten (in euro per ha bos) van particuliere bedrijven met meer dan 5 ha bos. De resultaten zijn gebaseerd op de administraties van circa 150 bedrijven. De administraties hebben alleen betrekking op de opbrengsten en kosten van het bosbedrijf.

Alle eigenaren van minimaal 5 ha bos zijn indertijd geregistreerd door het Bosschap - het intussen opgeheven bedrijfschap voor bos en natuur. Daarbij is onderscheid gemaakt tussen publiekrechtelijk bosbezit, zoals de boseigendommen van het Rijk (waaronder Staatsbosbeheer, Domeinen, Defensie), provincies, waterschappen en gemeenten, en privaatrechtelijk bosbezit.

De populatie van het Informatienet particuliere bosbedrijven (verder aangeduid met 'het Informatienet') wordt gevormd door de privaatrechtelijke boseigenaren, met uitzondering van de natuurbeschermingsorganisaties. In 2012 waren er 1.520 van dergelijke bedrijven met een bosbezit van bijna 63.000 ha (tabel B2.3).

Bij de opzet van het Informatienet is de populatie ingedeeld naar omvang van het bosbezit en de regionale ligging van de bedrijven, twee belangrijke kenmerken voor het onderzoek naar de bedrijfsuitkomsten. Van 1975 tot 1989 bestond de populatie uit bedrijven met meer dan 50 ha bos; in 1989 is de ondergrens verlaagd naar 5 ha. De bedrijven zijn ingedeeld in vijf oppervlakteklassen. In tabel B2.3 is het aantal bedrijven en de omvang van het bosareaal per klasse opgenomen.

\footnotetext{
${ }^{12}$ H.J. Silvis en M.J. Voskuilen, 2015.
} 
Tabel B2.3 Particuliere bosbezittingen naar oppervlakte en regio, 2012

\begin{tabular}{lrr} 
& Aantal bedrijen & \\
\hline Oppervlakte & 904 & Bosareaal (ha) \\
\hline 5 tot 25 ha & 219 & 10.328 \\
\hline 25 tot 50 ha & 131 & 7.517 \\
\hline 50 tot 100 ha & 70 & 8.850 \\
\hline 100 tot 250 ha & 40 & 10.315 \\
\hline 250 ha en meer & 21.747 \\
\hline Regio & 637 & 370 \\
\hline Noordoost & 357 & 25.060 \\
\hline Centrum & & 18.645 \\
\hline Zuid & 15.052 \\
\hline Totalen & 1.364 & 156 \\
\hline Doelpopulatie & 1.520 & \\
\hline Overig Nederland & 3.996 \\
\hline Totaal & 62.754 \\
\hline
\end{tabular}

Bron: Bosschap, bewerking Wageningen Economic Research.

De tweede indeling - regionale ligging van de particuliere bosbedrijven - is gebaseerd op de derde Nederlandse Bosstatistiek. De daarin voorkomende acht gebieden zijn samengevoegd tot vier regio's: Noordoost: ten oosten en ten noorden van de IJssel, met uitzondering van de noordelijke klei- en laagveengebieden; Centrum: Veluwe, Utrechtse Heuvelrug en Gooi; Zuid: Noord-Brabant en Limburg, met uitzondering van het rivierengebied; Overig Nederland. Uit de weinig bosrijke regio 'Overig Nederland' is geen steekproef getrokken, zodat deze in het periodieke rapport buiten beschouwing blijft. Ook in de uitkomsten per grootteklasse en voor alle bedrijven zijn de bedrijven uit Overig Nederland niet opgenomen. Hiermee komt de uiteindelijke doelpopulatie van het Informatienet uit op 1.364 particuliere bosbedrijven met een areaal bos van 58.757 ha (tabel B2.3).

In 2013 hebben de particuliere bosbedrijven gemiddeld een positief resultaat geboekt: 24 euro per ha bos tegenover 14 euro in 2012. Het positieve resultaat in 2013 is in hoofdzaak te danken aan de hoge houtprijs in combinatie met een behoorlijk oogstvolume. Vanaf 2006 zijn vooral door de stijging van de houtprijzen de meeste jaren met een plus afgesloten (figuur B2.2). In de laatste vijf jaar (20092013 ) is een positief resultaat behaald van gemiddeld 13 euro per ha per jaar, tegenover een verlies van 64 euro per ha per jaar in de periode 2001-2005. Ook in de jaren daarvoor waren de gemiddelde opbrengsten onvoldoende om de gemiddelde kosten te dekken.

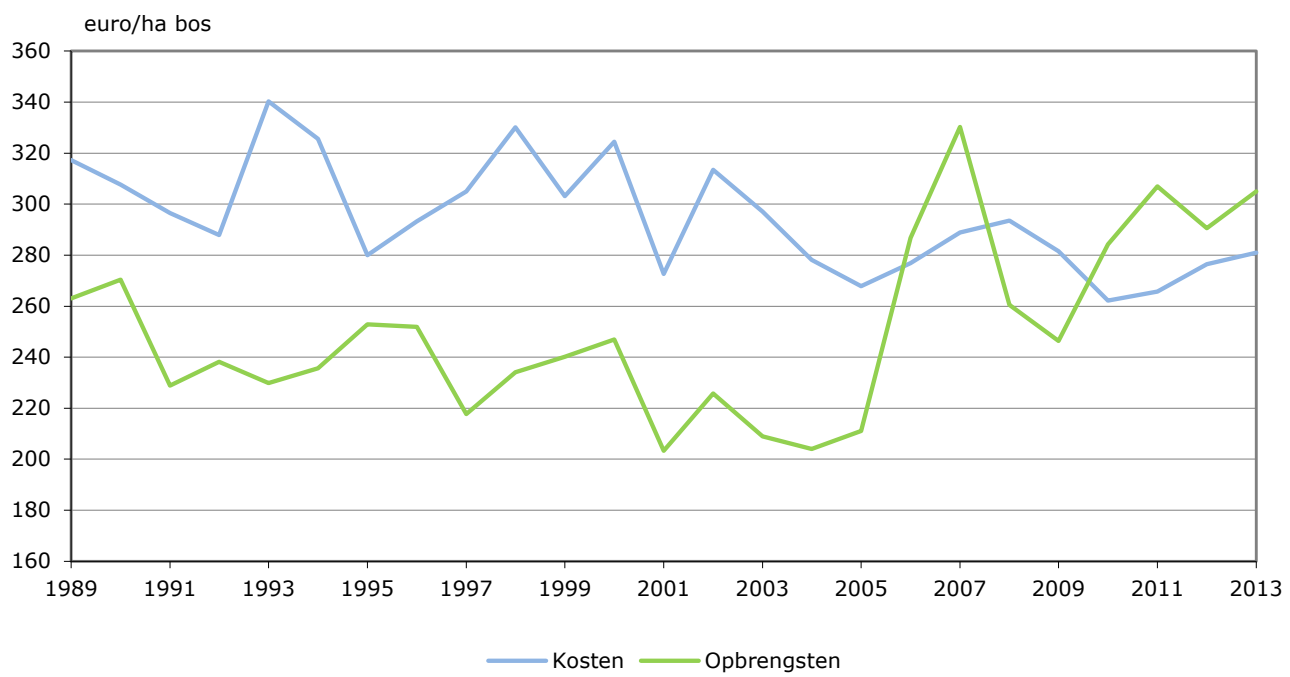

Figuur B2.2. Reële kosten en opbrengsten per ha bos (in euro's van 2013) op particuliere bosbedrijven, 1989-2013

Bron: Informatienet, Wageningen Economic Research. 
Het gemiddelde inkomen uit het bosbedrijf - dat is het bedrijfsresultaat zonder de berekende arbeidskosten (in hoofdzaak van de eigenaar) - kwam in 2013 uit op 67 euro per ha, tegenover 54 euro per ha in 2012. Vanaf de sterke stijging van de houtprijzen in 2006 is elk jaar een positief inkomen behaald. In de periode 2001-2005 resteerde een negatief inkomen van gemiddeld 27 euro per ha per jaar.

De resultaten van de particuliere bosbedrijven lopen sterk uiteen. Zo had in 2013 een derde van de bedrijven een tekort op de exploitatie van meer dan 100 euro per ha en ruim een vijfde een positief resultaat van meer dan 100 euro per ha. Het aandeel van de bedrijven met een positief resultaat is de afgelopen jaren toegenomen in vergelijking met de eerste helft van het decennium: van gemiddeld 24\% over de jaren 2001-2005 tot 43\% over de laatste drie jaar. De particulieren die in de laatste drie jaar uit de rode cijfers bleven, beheerden een areaal van 53\%. Tussen 2001-2005 beheerde de groep met een positief resultaat gemiddeld $41 \%$ van het areaal. 
Wageningen Economic Research Postbus 29703

2502 LS Den Haag

T 0703358330

Ecommunications.ssg@wur.nl

www.wur.nl/economic-research

Wageningen Economic Research RAPPORT

2016-090
De missie van Wageningen University \& Research is 'To explore the potential of nature to improve the quality of life'. Binnen Wageningen University \& Research bundelen Wageningen University en gespecialiseerde onderzoeksinstituten van Stichting Wageningen Research hun krachten om bij te dragen aan de oplossing van belangrijke vragen in het domein van gezonde voeding en leefomgeving. Met ongeveer 30 vestigingen, 5.000 medewerkers en 10.000 studenten behoort Wageningen University \& Research wereldwijd tot de aansprekende kennisinstellingen binnen haar domein. De integrale benadering van de vraagstukken en de samenwerking tussen verschillende disciplines vormen het hart van de unieke Wageningen aanpak. 



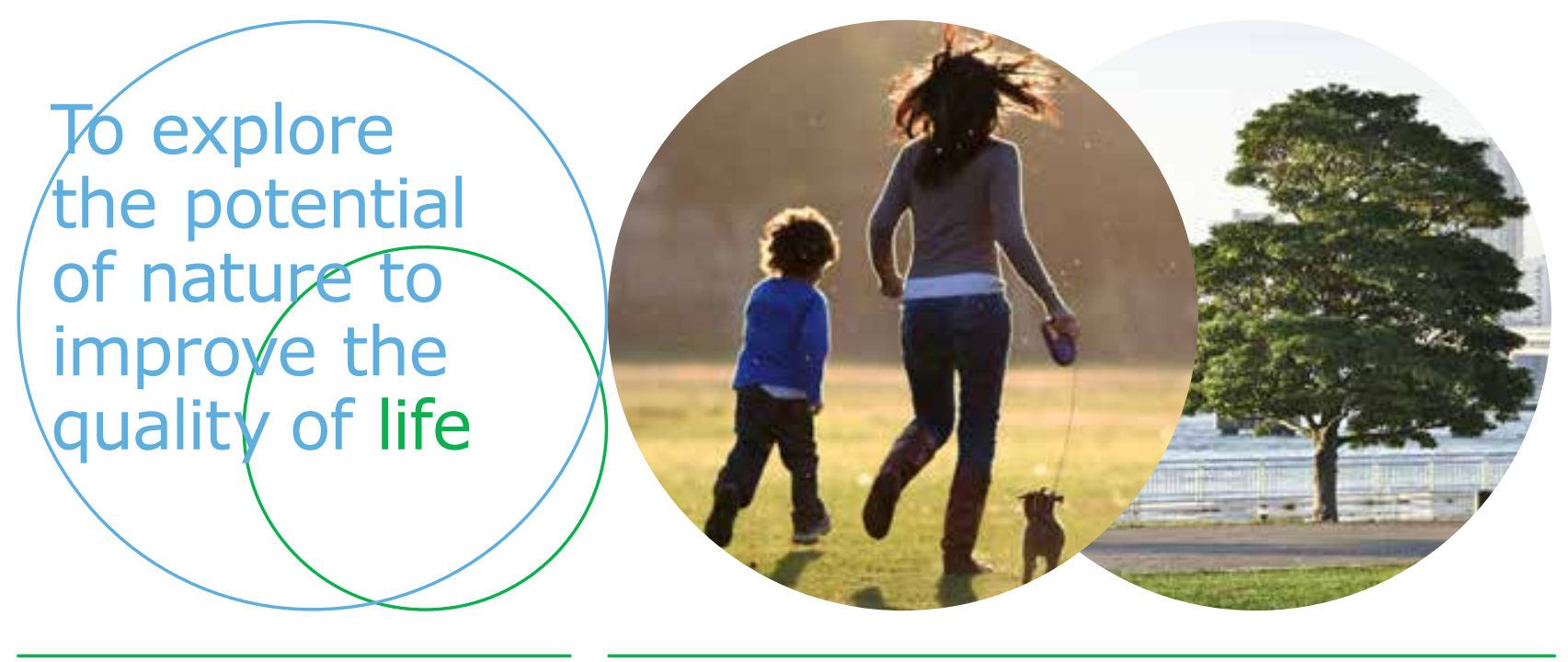

Wageningen Economic Research Postbus 29703

2502 LS Den Haag

E communications.ssg@wur.nl

$\mathrm{T}+31(0) 703358330$

www.wur.nl/economic-research

Rapport 2016-090

ISBN 978-94-6257-973-6
De missie van Wageningen University \& Research is 'To explore the potential of nature to improve the quality of life'. Binnen Wageningen University \& Research bundelen Wageningen University en gespecialiseerde onderzoeksinstituten van Stichting Wageningen Research hun krachten om bij te dragen aan de oplossing van belangrijke vragen in het domein van gezonde voeding en leefomgeving. Met ongeveer 30 vestigingen, 5.000 medewerkers en 10.000 studenten behoort Wageningen University \& Research wereldwijd tot de aansprekende kennisinstellingen binnen haar domein. De integrale benadering van de vraagstukken en de samenwerking tussen verschillende disciplines vormen het hart van de unieke Wageningen aanpak. 